Immobilization of the glucose isomerase from Caldicoprobacter algeriensis on Sepabeads EC-HA and its efficient application in continuous High Fructose Syrup production using packed bed reactor

Sawssan Neifar, Fadia V. Cervantes, Hajer BenHlima, Amel BouananeDarenfed, Antonio O. Ballesteros' Francisco J. Plou, Samir Bejar

PUBLISHED IN:

Food Chemistry Volume 309, 30 March 2020, 125710

DOI: https://doi.org/10.1016/j.foodchem.2019.125710 


\section{Immobilization of the glucose isomerase from Caldicoprobacter algeriensis on Sepabeads EC-HA and its efficient application in continuous High Fructose Syrup production using packed bed reactor}

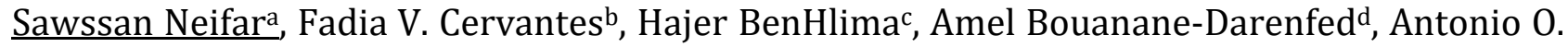
Ballesteros $^{\mathrm{b}, \text { Francisco J. Plou }}{ }^{\mathrm{b}}$, Samir Bejara*

a: Laboratory of Microbial Biotechnology and Engineering Enzymes (LMBEE), Centre of Biotechnology of Sfax (CBS), University of Sfax, Road of Sidi Mansour Km 6, PO Box 1177, Sfax 3018, Tunisia.

b: Institute of Catalysis and Petrochemistry, CSIC, Marie Curie 2, 28049 Madrid, Spain.

c: Unit of Algae Biotechnology, Biological Engineering Department, National School of Engineers of Sfax, University of Sfax, Sfax 3038, Tunisia.

d: Laboratory of Cellular and Molecular Biology (LCMB), Microbiology Team, Faculty of Biological Sciences, University of Sciences and Technology of Houari Boumediene (USTHB), PO Box 32, El Alia, Bab Ezzouar, 16111, Algeria.

Sawssan Neifara ${ }^{a}$ neifarsawssan@yahoo.fr), Fadia V. Cervantes ${ }^{b}$ (fadiacervantes@gmail.com), Hajer Ben Hlima (hajer_benhlima@yahoo.fr), Amel Bouanane-Darenfed ${ }^{\mathrm{d}}$ (amelbouanane@gmail.com), Antonio 0. Ballesteros ${ }^{b}$ (a.ballesteros@icp.csic.es), Francisco J. Ploub (fplou@icp.csic.es), Samir Bejara*(samir.bejar@cbs.rnrt.tn).

\section{*Corresponding author:}

Samir Bejar (samir.bejar@cbs.rnrt.tn)

Tel: +21698550 009, Tel./Fax: +21674870451 


\section{ABSTRACT}

The glucose isomerase GICA from Caldicoprobacter algeriensis was immobilized by ionic adsorption on polymethacrylate carriers (Sepabeads EC-EA and EC-HA) or covalent attachment to glyoxal agarose. The Sepabeads EC-HA yielded the highest recovery of activity (89\%). The optimum temperature and $\mathrm{pH}$ of immobilized GICA were $90^{\circ} \mathrm{C}$ and 7.0 , respectively, similar to the corresponding values of free enzyme. Nevertheless, the adsorbed enzyme displayed higher relative activity at acidic $\mathrm{pH}$, greater thermostability, and better storage stability, compared to the free form. Moreover, the immobilized enzyme showed an excellent operational stability, in 15 successive $3 \mathrm{~h}$ reaction cycles at $85^{\circ} \mathrm{C}$ under a batch reactor, preserving $83 \%$ of its initial activity. Interestingly, a continuous process for High Fructose Syrup (HFS) production was established with the adsorbed GICA using a packed bed reactor during eleven days at $70{ }^{\circ} \mathrm{C}$. HPAEC-PAD analysis showed a maximum bioconversion rate of $49 \%$ after $48 \mathrm{~h}$ of operation.

\section{Graphical abstract:}

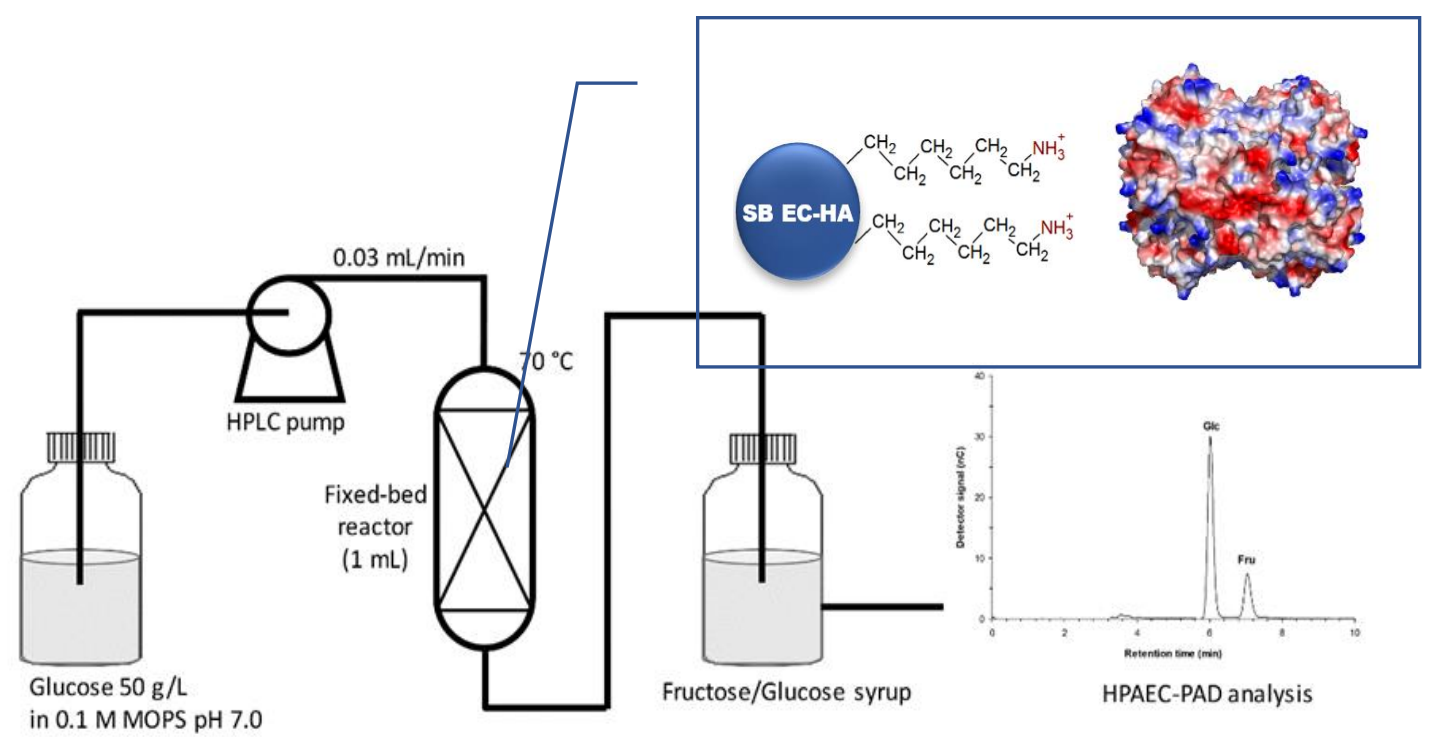

\section{Key words}

Glucose isomerase, Enzyme immobilization, Sepabeads, Batch reactor, Packed Bed Reactor, HFS. 


\section{Chemical compounds}

Chemical compounds studied in this article:

Sodium borohydride (PubChem CID: 4311764).

\section{Highlights}

$\checkmark$ The GICA was immobilized onto amino supports with very high recovery yield.

$\checkmark$ The adsorbed GICA showed an improvement on its thermo-stability.

$\checkmark$ An excellent operational stability in batch reactor cycles was observed at $85^{\circ} \mathrm{C}$.

$\checkmark$ A continuous packed bed reactor system was established for HFS production. 


\section{INTRODUCTION}

Glucose isomerase (GI) has received a great interest in food industry mainly in High Fructose Syrup (HFS) production, thanks to its ability to convert D-glucose into D-fructose in vitro (Shakoor, Singh, \& Singh, 2018).This liquid mixture of glucose and fructose (HFS), generally recognized as safe (GRAS), has aroused a great attention to the world's sweetener market due to its better technical and functional properties over sucrose such as flavor enhancer, good humectant, no crystal formation, good stability in acidic foods, etc. (White, 2014). These outstanding functional properties allow its application as an important food ingredient in many foodstuffs including yogurt, ice-cream, chocolate milk and beverage (Zargaraan, Kamaliroosta, Yaghoubi, \& Mirmoghtadaie, 2016).

Conventionally, HFS is prepared from starch using multi enzymatic process (Singh, Chauhan, Pandey, \& Larroche, 2018). Recently, several studies have inclined toward the use of another raw material for the production of this syrup such as cheese whey, a low-cost by product of the cheese industry (Araya, Urrutia, Romero, Illanes, \& Wilson, 2019). The crucial step in HFS production process is isomerization which is widely performed by free or whole cell GI (Dehkordi, Tehrany, \& Safari, 2009).

Nevertheless, the industrial application of this biocatalyst in its original form is often impeded by several drawbacks like cost production, low operational stability, tedious separation after the achievement of the bioconversion and failure in reusability, among other factors (Bedade, Sutar, \& Singhal, 2019). Thereby, these deficiencies could be overcome through the immobilization of the enzyme. Basically, the immobilization strategies can be divided into three major groups: carrier binding (by adsorption or covalent linkages), entrapment and crosslinking (Míguez, Gimeno-Pérez, Fernández-Polo, Cervantes, Ballesteros, Fernández-Lobato, et al., 2018). Physical adsorption via van der Waals or hydrophobic interactions is too weak to avoid the leakage of the enzyme from the carrier during the reaction (Jesionowski, Zdarta, \& Krajewska, 2014).

To circumvent this limitation, physical binding via electrostatic interaction is an alternative method to provide a robust interaction (Ali, Zafar, Shafiq, \& Manzoor, 2017). The main benefits of ionic adsorption process are simplicity, low cost, regeneration of support and high retention of enzyme activity (Fernandes, 2010). Apart from immobilization strategies, carriers are also a crucial factor that should be taken into account (Zhong, Chen, Liu, \& Chen, 2019). Ideally, the support should create a robust enzyme-matrix interaction and minimize diffusion restrictions of the substrates (Drout, Robison, \& Farha, 2019).

Special attention should also be paid to the recovery of the immobilized biocatalyst step which must be simple, fast and cost-effective like filtration (Mohamad, Marzuki, Buang, Huyop, \& Wahab, 2015; Rios, Pinheiro, Pinheiro, Bezerra, dos Santos, \& Gonçalves, 2018). Among supports, Sepabeads EC carriers are highly porous polymethacrylate synthetic carriers with average pore diameter of $30-40 \mathrm{~nm}$ and a particle size distribution of $100-300 \mu \mathrm{m}$. These supports display noteworthy properties including: high mechano-osmotic stability, low compressibility, high resistance to microbial attacks and easy separation of the immobilized enzyme from medium reaction (Demir \& Önal, 2018).

In addition, the raw materials used for the production of these supports are involved in the EU list of register for the processing of food stuff (Prlainović, Knežević-Jugović, Mijin, \& Bezbradica, 2011). Thanks to their excellent properties, Sepabeads carriers, with different functional 
groups, have been successfully used for the immobilization of numerous biocatalysts and applied for continuous or batch operating modes (Hilterhaus, Minow, Müller, Berheide, Quitmann, Katzer, et al., 2008). Continuous operation using packed bed column is more advantageous and cost-effective which is widely used in the food industry(Kolev, 2006). Consequently, the application of immobilized enzyme in industrial processes depend on biocatalyst form (cells or free soluble enzyme), carriers and the strategy for its immobilization.

Notwithstanding, GI is typically employed in the industry in the form of immobilized wholecells (Jia, Wang, Liu, Jin, Li, Liao, et al., 2018), however, severe diffusional limitations lower the catalytic efficiency of this biocatalyst (Fernandez-Arrojo, Rodriguez-Colinas, Gutierrez-Alonso, Fernandez-Lobato, Alcalde, Ballesteros, et al., 2013). Hence, an extensive number of immobilization methods have been previously reported for GI's (DiCosimo, McAuliffe, Poulose, \& Bohlmann, 2013). Nevertheless, the majority of them have some deficiencies like low operational stability (Jin, Xu, Liu, Jia, Liao, Chen, et al., 2017) or the requirement of toxic substances like glutaraldehyde that could cause several environmental hazards during the scale up of the process. Hence, the development of a straightforward and eco-friendly strategy for GI immobilization is still required to comply with the economic requirements for large-scale.

In our previous study, a novel thermostable and efficient glucose isomerase GICA from Caldicoprobacter algeriensis was proved to be an interesting candidate for HFS production (Neifar, Hlima, Mhiri, Mezghani, Bouacem, Ibrahim, et al., 2019). In spite of its excellent catalytic properties, the implementation of GICA at industrial level requires its immobilization on solid supports in order to trim down the cost of HFS production. Wherefore, the present study is intended to determine a suitable support using an eco-friendly and simple method, with no chemical reagent addition. Further, the adsorbed GICA on Sepabeads EC-HA was biochemically characterized and compared with respect to free counterpart. The operational stability of the immobilized enzyme was assessed under batch conditions. Additionally, our immobilized enzyme was employed for a continuous HFS production using a fixed-bed reactor. 


\section{MATERIALS AND METHODS}

\subsection{Supports and reagents}

Sepabeads EC-EA and EC-HA were kindly offered by Resindion S.R.L (Mitsubishi Chemical Corporation, Italy). High Density Glyoxal Agarose Resin 4BCL-GH1 and the column 1-mL EBCtg1-1 cartridge (6.2 mm inner column diameter) were purchased from Agarose Bead Technologies (Torrejon de Ardoz, Madrid, Spain). The micro-centrifuge filter tubes (with 0.45 ? $\mathrm{m}$ cellulose acetate membranes) were purchased from Costar (Spin-X, Corning Inc.). Glucose, fructose and MOPS were from Sigma-Aldrich (Tres Cantos, Madrid, Spain).

\subsection{Production, extraction and lyophilization of GICA enzyme}

The production and extraction of the recombinant enzyme GICA were performed as previously described by Neifar et al., (Neifar, et al., 2019). The obtained soluble crude extract enzyme was partially purified by heat treatment for $30 \mathrm{~min}$ at $90{ }^{\circ} \mathrm{C}$ in the presence of $0.5 \mathrm{mM} \mathrm{CoCl} 2$ and 20 $\mathrm{mM} \mathrm{MgCl}$. Subsequently, the precipitated protein was discarded by centrifugation $(12000 \mathrm{rpm}$, $30 \mathrm{~min}$ ) and the supernatant, containing GICA enzyme, was lyophilized and stored at $4{ }^{\circ} \mathrm{C}$ until further use.

\subsection{Selection of the suitable support for GICA immobilization}

\subsubsection{Covalent immobilization}

Glyoxal agarose was used as carrier for GICA covalent immobilization. In order to deprotonate amino residues of the enzyme and allow the conjugation with aldehyde resin groups, the immobilization was performed at alkaline $\mathrm{pH}$. The immobilization process was performed following a methodology described in a previous work (Fernandez-Arrojo, Santos-Moriano, Rodriguez-Colinas, Ballesteros, \& Plou, 2015). Briefly, the glyoxal agarose support ( $300 \mu \mathrm{L})$ was added inside a micro-centrifuge filter tube with $0.45 \mu \mathrm{M}$ cellulose membrane and washed three times using $10 \mathrm{mM}$ MOPS buffer ( $\mathrm{pH} 9.0$ ). Afterwards, a defined amount of enzyme from a stock solution $(100 \mathrm{mg} / \mathrm{mL})$ was mixed with the carrier and incubated at room temperature for $6 \mathrm{~h}$ in roller mixer. Subsequently, $3 \mathrm{mg}$ of $\mathrm{NaBH}_{4}$ was added to the suspension in order to reduce the Schiff's base formed between an aldehyde and an amine. The resulting biocatalyst was washed three times with $10 \mathrm{mM}$ MOPS buffer (pH 7.0).

\subsubsection{Adsorption immobilization}

Two different carriers activated with amino groups, Sepabead EC-EA and Sepabead EC-HA, were assessed to immobilize GICA enzyme. These two carriers differ in the length of spacer arm: two carbon atoms (EA, ethylendiamino) and six carbon atoms (HA, hexamethylenamino). $250 \mathrm{mg}$ of the carrier (Sepabeads EC-EA or EC-HA) were weighed inside a micro-centrifuge filter tube and then washed three times with $500 \mu \mathrm{L}$ of immobilization buffer to equilibrate the support (10 mM MOPS, pH 7.0). The washing step included the mixture of the carrier with the buffer by closing the microfilter tube and inverting 6 times, followed by a centrifuge spin for the separation of the washing buffer from the solid particles, which remained inside the filter holder. After washing, the amino-activated resin was mixed (inside the filter holder) with 150 $\mu \mathrm{L}$ of enzyme solution of glucose isomerase (stock solution $100 \mathrm{mg} / \mathrm{mL}$ ) and $350 \mu \mathrm{L}$ of $10 \mathrm{mM}$ MOPS pH 7.0. After $24 \mathrm{~h}$ of incubation at room temperature in a roller mixer (J.P. Selecta), the filter tubes were centrifuged at 5,000 $\mathrm{x}$ g and the filtrate was collected and stored. The resulting biocatalyst was washed three times, with $500 \mu \mathrm{L}$ of reaction buffer (10 mM MOPS, pH 7.0) and 
inverting the micro-filter tube 6 times, followed by a filtration step by centrifugation. The washing solutions 1,2 and 3 were collected and stored at $4^{\circ} \mathrm{C}$. The activity and protein concentration of the filtrate and washings was measured as described above. The immobilization yield was determined by subtracting the total protein and enzymatic activity in the filtrate and the washing solutions from the initial values in the enzyme solution.

\subsection{Loading capacity and determination of protein concentration}

Different amounts of GICA were added to $250 \mathrm{mg}$ of Sepabeads-EC-HA and incubated at room temperature for $24 \mathrm{~h}$. Then, all immobilized preparations with different enzyme loadings were washed with MOPS buffer. The apparent activity (U/g support) was compared with the theoretical activity for each immobilized load. The protein concentrations were assayed in microtiter plates according to the Bradford method (Bradford, 1976).

\subsection{Biochemical characterization of both free and immobilized GICA}

\subsubsection{Optimum temperature and thermal stability}

The optimum temperature for free and immobilized enzymes was determined by performing the standard activity assay procedure, at different temperatures ranging from 50 to $95{ }^{\circ} \mathrm{C}$ as previously described by Neifar et al., (Neifar, et al., 2019). The relative activities (\%) were expressed as the ratio of the maximum activity obtained at the given temperature range. For thermostability, the free and immobilized enzymes (without substrate) were incubated at different temperatures $\left(85^{\circ} \mathrm{C}, 80^{\circ} \mathrm{C}, 75^{\circ} \mathrm{C}\right.$ and $\left.70^{\circ} \mathrm{C}\right)$ for several days. At definite time intervals aliquots were withdrawn, cooled immediately and tested for residual enzyme activity using standard assay.

\subsubsection{Optimum $p H$ and stability}

The effect of $\mathrm{pH}$ on activity of free and immobilized GICA was determined by assaying the enzyme activity at various pH values ranging from 5.0 to 10.0 using $100 \mathrm{mM}$ MOPS-NaOH buffer. The $\mathrm{pH}$ stability profile of both free and immobilized enzyme was performed at $\mathrm{pH}$ 7.0, 6.5 and 6.0 using $100 \mathrm{mM}$ MOPS buffer. The residual activity (\%) with respect to control was determined.

\section{$2.6 \quad$ Storage stability}

The storage stability of free and immobilized GICA was carried out by measuring their activities after being stored at $4{ }^{\circ} \mathrm{C}$. The remaining activities (\%) were assayed after each $24 \mathrm{~h}$. The nonincubated enzymes were considered as control.

\section{$2.7 \quad$ Operational stability of immobilized glucose isomerase under batch reaction}

For operational stability, the reaction was performed as illustrated in Figure.S1 using a microscale procedure (Fernandez-Arrojo, Santos-Moriano, Rodriguez-Colinas, Ballesteros, \& Plou, 2015). The reaction was incubated at $85^{\circ} \mathrm{C}$ for $3 \mathrm{~h}$. After each batch, the immobilized enzymes were separated from the reaction medium by centrifugation and washed thoroughly with MOPS buffer to remove any residual substrate and products. Subsequently, beads were reused for the next batch. The process was repeated several times. The activity of the first batch was considered as $100 \%$. 


\subsection{Continuous HFS production using packed bed reactor}

One gram of Sepabeads EC-HA was washed three times with $1 \mathrm{~mL}$ of $10 \mathrm{mM}$ MOPS buffer pH 7.0 to equilibrate the support. After washing, the amino-activated resin was mixed with $120 \mathrm{mg}$ of enzyme and an appropriate buffer volume was added to a total volume of $1 \mathrm{~mL}$. After $24 \mathrm{~h}$ incubation at room temperature in a tube rotator, the mixture was filtrated and the resulting biocatalyst was washed three times, with $1 \mathrm{~mL}$ of reaction buffer (10 mM MOPS, pH 7.0). The adsorbed GICA was packed in a 1-mL EB-Ctg1-1 cartridge (6.2 mm inner column diameter, Agarose Bead Technologies). The inlet of the column was connected to a HPLC pump (Waters 515 ) in order to control the flow of the feeding solution ( $50 \mathrm{~g} / \mathrm{L}$ glucose, $20 \mathrm{mM} \mathrm{MgCl}, 0.5 \mathrm{mM}$ $\mathrm{CoCl}_{2}$ in $0.1 \mathrm{M}$ MOPS buffer $\mathrm{pH} 7.0$ ) which was maintained at $0.03 \mathrm{~mL} \mathrm{~min}^{-1}$ The column comprising the immobilized enzyme GICA was maintained at $70{ }^{\circ} \mathrm{C}$ during eleven days. At different times, an aliquot was taken from the outlet stream of the bioreactor and used for HPAEC-PAD analysis

\subsection{Determination of glucose isomerase activity and isomerization product analysis}

The glucose isomerase activity was performed using glucose-oxidase (GOD-PAP) enzyme system kit (Biomaghreb, Tunisia) (Neifar, et al., 2019). Product analysis (D-glucose and Dfructose) was carried out by high performance anion-exchange chromatography coupled with pulsed amperometric detection (HPAEC-PAD) on an ICS3000 Dionex system consisting of a SP gradient pump, an electrochemical detector with a gold working electrode and $\mathrm{Ag} / \mathrm{AgCl}$ as reference electrode, an autosampler (model AS-HV), and a PC 10 post-column delivery system with $0.2 \mathrm{M} \mathrm{NaOH}$. All eluents were degassed by flushing with helium. A pellicular anionexchange 4 × $250 \mathrm{~mm}$ Carbo-Pack PA-1 column (Dionex) connected to a 4 x 50 CarboPac PA-1 guard column was used at $30^{\circ} \mathrm{C}$. Eluent preparation was performed with MilliQ water, $50 \%$ (w/v) NaOH (Sigma-Aldrich) and sodium acetate trihydrate (Fisher Chemical). The peaks were analyzed using Chromeleon software.

One unit (U) of activity was defined as the corresponding to the isomerization of one $\mu$ mole of glucose into fructose per minute.

\subsection{Scanning Electron Microscopy}

In order to analyze the homogeneity and particle size of the Sepabeads EC-HA carrier microspheres, the dried sample was metallized with gold in a sputter Quorum, model Q150T-S and analyzed on Scanning electron microscopy (SEM) employing a S-3000N microscope (Hitachi, Schaumburg, IL, USA).

\subsection{Homology Modeling}

The 3D model of GICA and the graphical presentations were carried out as described by Neifar et al.,(Neifar, et al., 2019) using Swiss-model server and the PyMol Molecular Graphics, respectively.

\subsection{Statistical analysis}

The mean of triplicates assays with their standard deviation or standard error (mean \pm SD) were calculated using Graph Pad Prism (version 6). 


\section{RESULTS AND DISCUSSION}

\subsection{Determination of a suitable support for GIGA immobilization}

The first objective of the present study was to determine a suitable support for GICA immobilization using a simple and eco-friendly method. Thanks to the high number of charged residues on the GICA surface (Neifar, et al., 2019), we evaluated its adsorption on charged resins. Therefore, GICA was immobilized by ionic adsorption on Sepabeads EC-EA and EC-HA. The results were compared with the covalent attachment onto glyoxyl-activated agarose.

As depicted in Table 1, using the glyoxal agarose as support, the apparent (experimental) activity of the immobilized GICA was approximately $0.93 \mathrm{U} / \mathrm{g}$. The net recovery of activity was close to $5 \%$ of the initial activity (the theoretical value was $22 \%$ ). This observation could be attributed to the change of enzyme conformation instigated by covalent bonds (Abbaszadeh \& Hejazi, 2019), the orientation of active site towards the support surface (Demir \& Önal, 2018) or to the surface density of reactive amino groups on the enzyme surface (Prlainović, KneževićJugović, Mijin, \& Bezbradica, 2011).

Nonetheless, the adsorption onto amino resins (Sepabeads) gave better results than the covalent binding, with theoretical recovery activity (measuring the activity in filtrate and washings) between 82-89 \%. These percentages were higher compared to those reported in the literature. As an example, the recovery activity in optimized conditions of the immobilized $\alpha$-galactosidase onto Sepabeads EC-EA support activated with aminophenylboronic acid (APBA) was $72 \%$ (Demir \& Önal, 2018). The apparent activity of the resulting biocatalysts (GICA)was $10.2 \mathrm{U} / \mathrm{g}$ for Sepabeads EC-EA and $12.5 \mathrm{U} / \mathrm{g}$ for EC-HA. These values were lower than the expected theoretical activities, as typically occurs with immobilized biocatalysts due to diffusional restrictions compared with the soluble enzyme (Fernandez-Arrojo, et al., 2013). This decrease on apparent activity could be ascribed to the presence of reactive negatively charged groups which were located in the vicinity of the active site. As shown in Figure S2, hydroxyl groups of serine, threonine, and tyrosine could participate in the ionic interactions with functional group of Sepabeads $\left(\mathrm{NH}_{3}{ }^{+}\right)$, and therefore hamper the substrate entrance to the catalytic site.

As shown in Table1, Sepabeads EC-HA gave a slightly better performance than EC-EA. One possible explanation is the longer spacer arm of the support that reduces the diffusional restriction (Bryjak \& Trochimczuk, 2006; Prlainović, Knežević-Jugović, Mijin, \& Bezbradica, 2011). Similar observations have been previously reported by others works that used supports with longer spacer arms for immobilization (Bryjak \& Trochimczuk, 2006; Prlainović, KneževićJugović, Mijin, \& Bezbradica, 2011). The excellent recovery of activity with Sepabeads amino carriers could be related also to the high density of charged residues on the GICA enzyme surface (Figure. S3). Thereby, Sepabeads EC-HA was selected as the best support for GICA immobilization. The surface morphology of the dried Sepabeads EC-HA was analyzed by SEM. This carrier has a particle size distribution of 100-200 $\mu \mathrm{m}$ ( $\underline{\text { Fig. 1) }}$ ).

There are several reports on immobilization of glucose isomerase on various carriers using different strategies (Desai, Gachhi, \& Hungund, 2016). Nevertheless, to the best to our knowledge, this is the first study that describes the immobilization of glucose isomerase on Sepabeads supports. Additionally, the immobilization method described in this current study is quite simple and eco-friendly compared with the other immobilization methods that required various reagents like glutaraldehyde. This crosslinker reactive is not only toxic but it may cause 
the denaturation of the immobilized enzyme (Prlainović, Knežević-Jugović, Mijin, \& Bezbradica, 2011).

\subsection{Capacity of supports}

Enzyme concentration, is one of the most common factors that should be taken into consideration to improve enzyme immobilization and activity yields (Abbaszadeh \& Hejazi, 2019). Subsequently, the capacity of Sepabeads EC-HA was assessed. The obtained result unveiled that an increase on biocatalyst concentration loading led to an increase on the apparent activity of the immobilized enzyme and therefore on bioconversion rate until a maximum concentration of $120 \mathrm{mg}$ of enzyme per gram of support. Up to this concentration, the recovery activity of the adsorbed enzyme decreased gradually (data not shown). This observation could be ascribed to the accumulation of enzyme on the surface of carrier, which results in steric hindrance that limit the contact of the substrate with the active site of the enzyme. To avoid this overcrowding of enzyme loading, we selected $120 \mathrm{mg}$ of GICA per gram of carrier as the optimal concentration in the subsequent experiments. In a previous study, the maximum amount of the immobilized lipase from Candida rugosa on glutaraldehyde activated Sepabeads EC-HA was 90.9 mg/g of support (Prlainović, Knežević-Jugović, Mijin, \& Bezbradica, 2011). This slightly difference on the amount enzyme concentration could be accredited to type of enzyme.

\subsection{Biochemical properties of free and immobilized glucose isomerase}

The support can significantly improve several enzyme features such as stability and substrate affinity (Suryawanshi, Jana, Prajapati, \& Kango, 2019). In order to evaluate the impact of immobilization on biochemical properties of GICA, a comparative study between the two forms was performed in terms of temperature and $\mathrm{pH}$ activity/stability.

\subsubsection{Influence of temperature on enzyme activity and stability}

The impact of temperature on the enzyme activity for both free and immobilized GICA was inspected. As portrayed in Figure. S4, both forms displayed the same optimal activity of $90^{\circ} \mathrm{C}$. In a similar study, Prlainović et al., (Prlainović, Knežević-Jugović, Mijin, \& Bezbradica, 2011) and Demir et al., (Demir \& Önal, 2018) reported that the immobilization of lipase on both Sepabeads EC-HA and Sepabeads EC-EA did not affect the optimum temperature of the biocatalyst. On the other hand, an increase of the optimal reaction temperature from $37^{\circ} \mathrm{C}$ to $60^{\circ} \mathrm{C}$ was observed upon the immobilization of $\alpha$-galactosidase enzyme on Sepabeads EC-HA (Bayraktar, Serilmez, Karkaş, Çelem, \& Önal, 2011).

Additionally, the adsorbed GICA was more active than its counterpart form at all temperature bellow to $90{ }^{\circ} \mathrm{C}$ (Figure. S4). For instance, at $70{ }^{\circ} \mathrm{C}$ the immobilized GICA displayed about $80 \%$ of its maximum activity while it was merely $40 \%$ for the free form (Figure.S4). Several previous studies indicated that the immobilization onto amino resins improved the relative activity of enzyme at high temperature (Bayraktar, Serilmez, Karkaş, Çelem, \& Önal, 2011). As example, the immobilized lipase on Sepabeads (EC-HA and EC-EP) maintained around 70\% of its relative activity at $80{ }^{\circ} \mathrm{C}$, whereas, the free form had only 39\% (Prlainović, Knežević-Jugović, Mijin, \& Bezbradica, 2011).

On the other hand, thermal stability of immobilized enzyme could be enhanced, decreased or unchanged relative to free counterparts (Demir \& Önal, 2018). Generally, immobilization improved the lifespan and thermostability of the enzyme. In fact, the thermostability of the two 
forms of GICA was investigated and compared at various temperatures $\left(70,75,80\right.$ and $\left.85{ }^{\circ} \mathrm{C}\right)$. As portrayed in Fig.2, for all tested temperatures, the immobilized GICA was more stable in comparison to its free counterpart. For instance, the immobilized and free GICA retained 42 and $62 \%$, respectively of their initial activities after incubation for $20 \mathrm{~h}$ at $85^{\circ} \mathrm{C}$ (Fig. $\left.2 \mathrm{~A}\right)$. Moreover, the residual activities of the adsorbed and free GICA were 65.5 and $41.5 \%$ after $96 \mathrm{~h}$ at $80{ }^{\circ} \mathrm{C}$ (Fig.2 B). Interestingly, the Sepabeads EC-HA immobilized enzyme displayed $88 \%$ of its original activity after one-month incubation at $70{ }^{\circ} \mathrm{C}$, whereas the free form had merely $50 \%$ at the same condition ( Fig.2 D). The aforementioned results proved the effectiveness of the Sepabeads support at higher temperatures by rendering the immobilized biocatalyst more robust and resistant against thermo-inactivation (Bayraktar, Serilmez, Karkaş, Çelem, \& Önal, 2011). This result is in agreement with that has been noted by Alonso et al. concerning the increment of the thermal stability of the immobilized enzymes onto aminated supports (Alonso, López-Gallego, Betancor, Hidalgo, Mateo, Guisan, et al., 2005). In another study, the residual activities of the free and the immobilized $\alpha$-galactosidases onto Sepabeads EC-HA were correspondingly calculated as 65 and $18 \%$ of their initial activities after incubation for $90 \mathrm{~min}$ at $50{ }^{\circ} \mathrm{C}$ (Demir \& Önal, 2018).

Similar results about improving thermostability of immobilized GIs using various supports have been reported in literature (Araya, Urrutia, Romero, Illanes, \& Wilson, 2019; Jia, et al., 2018; Jin, et al., 2017; Tükel \& Alagöz, 2008). As example, Chen et al., described that the residual activities for free and immobilized GI from Streptomyces rubiginosus onto Eupergit C 250L were 97 and $84 \%$, respectively after $18 \mathrm{~h}$ incubation at $60^{\circ} \mathrm{C}$ (Tükel \& Alagöz, 2008). In contrast, the immobilized GI from Streptomyces flavogriseus onto benzyl DEAE-cellulose and TEAE-cellulose had the same thermostability profile as the free enzyme (Chen \& Anderson, 1979).

Thermostability is a very relevant factor which determines the potential implementation of enzyme in commercial scale process. Thanks to its high thermostability at $70{ }^{\circ} \mathrm{C}$, the adsorbed GICA could be an interesting candidate for HFS production in continuous large-scale processes.

\subsubsection{Influence of $\mathrm{pH}$ on the enzyme activity and stability}

The obtained outcomes showed that the maximum activities of free and immobilized GICA were obtained at pH 7 (Fig.3). This result is in compliance with those described by others researchers using Sepabeads as support for immobilization (Saponji, Kneevi-Jugovi, Bezbradica, Zuza, Saied, Boskovi-Vragolovi, et al., 2010; Torres \& Batista-Viera, 2012). While, in another study, a significant shift to the alkaline region of the optimum $\mathrm{pH}$ was observed in comparison to the free enzyme upon immobilization of both $\alpha$-galactosidase and lipase enzymes on the carriers with amino groups. According to authors, the reason for this trend could be ascribed to the increment of the acidic groups number that duct to the enzyme to gain more polyanionic character (Prlainović, Knežević-Jugović, Mijin, \& Bezbradica, 2011)

In addition, the $\mathrm{pH}$ profile of the immobilized biocatalyst GICA was broader than that of the free enzyme in alkaline range ( $\underline{\text { Fig. }}$ ). Interestingly, the immobilization of GICA on Sepabeads EC-HA enhanced the catalytic activity of the adsorbed enzyme in acidic $\mathrm{pH}$ range compared to its free counterpart. Indeed, as shown in Fig. 3, the immobilized enzyme displayed more than $85 \%$ at pH 6 and 6.5 of its maximum activity, whereas the free form had only 81\%. However, a significant increment on the relative activity was noted at pH 5 and 5.5 (Fig. 3 ). As example, the relative activities of the adsorbed GICA and free enzyme were approximately 80 and $60 \%$, respectively. Similar result about improving activity at acidic and alkaline $\mathrm{pH}$ of the immobilized $\alpha$-galactosidase on Sepabeads (EC-EA /EC-HA) has been previously reported in literature (Bayraktar, Serilmez, Karkaş, Çelem, \& Önal, 2011). 
The impact of $\mathrm{pH}$ on enzyme stability of the two forms was determined in the $\mathrm{pH}$ range from 6 to 7 at $4^{\circ} \mathrm{C}$ and the obtained results are plotted in Figure. S5. The adsorbed GICA was found to be more stable when compared to the native enzyme and more than $90 \%$ of its initial activity was recovered in in all tested $\mathrm{pH}$ after incubation for $360 \mathrm{~h}$ at $4^{\circ} \mathrm{C}$. This indicates that adsorbed GICA is more resistant towards $\mathrm{pH}$ changes. Improvement of $\mathrm{pH}$ stability for immobilized GI was also observed in various study (Jin, et al., 2017; Kamal, Hegazy, Sharada, Abd elhalim, Lotfy, \& Mohamed, 2014; Tumturk, Demirel, Altinok, Aksoy, \& Hasirci, 2008; Zhao, Cui, Shah, Xu, \& Wang, 2016).

These findings are valuable in high fructose syrup production process. Indeed, performing isomerization at acidic $\mathrm{pH}$ obviates the production of undesired by-products such as psicose and mannose, and affords to carry out the starch liquefaction and the isomerization reaction in one step process (Neifar, et al., 2019).

\subsection{Storage stability}

Storage stability is a relevant parameter for the implantation of biocatalysts on the commercial level. The residual activity of the immobilized and free GICA was measured every 15 days. The obtained results (data not shown) indicated that adsorbed GICA had a good storage stability and more than $95 \%$ of its residual activity was maintained after two months incubation at $4^{\circ} \mathrm{C}$. In contrast, the free enzyme retained only $85 \%$ of its initial activity under the same conditions. This result unveiled an increment shelf life thanks to the immobilization of GICA. Similar trend was also observed in previous study(Jin, et al., 2017).

\section{Operational performance of GICA under batch reaction}

Enzyme immobilization is a powerful tool to improve stability and reusability of enzymes. This latter is a paramount parameter to determine its candidature for industrial applications thus significantly trim down the cost of the production in large-scale processes (Bayraktar, Serilmez, Karkaş, Çelem, \& Önal, 2011; Bedade, Sutar, \& Singhal, 2019). Consequently, before setting up a continuous reactor, the operational performance of GICA was scrutinized by measuring its residual activity after each batch reaction. As shown in Fig.4, the adsorbed GICA showed a good stability and almost $89 \%$ of its initial activity was preserved after reused for 15 recycles with a total of $45 \mathrm{~h}$ operation at $85{ }^{\circ} \mathrm{C}$. Thereafter, the residual activity was steadily decreased by increasing the number of reuses. The loss of enzyme activity could result from the restructuring of the biocatalyst in reuse processes or from the enzyme leakage (Bayraktar, Serilmez, Karkaș, Çelem, \& Önal, 2011). Our immobilized GICA showed a higher operational stability compared to other immobilized GI's enzymes obtained by numerous immobilization methods. Indeed, in a study by Chopda et al., the immobilized GI on roughened PEI remained almost $89 \%$ of its initial activity at $70^{\circ} \mathrm{C}$ after being reused for 20 times (equivalent to $20 \mathrm{~h}$ of operation). In addition, the immobilized GI from Streptomyces rubiginosus onto Eupergit C $250 \mathrm{~L}$ retained 85\% of its original activity after recycled for 18 times (each cycle was $30 \mathrm{~min}$ ).

Generally, physical adsorption immobilization strategy provides weak affinity interactions between the carrier and the enzyme, thus dropping the reusability of the system. In contrast, our adsorbed biocatalysts possess an excellent operational stability at $85^{\circ} \mathrm{C}$ in large number of batches which is advantageous for the continuous use of enzyme in industrial applications. This observation is probably due to the strong electrostatic interaction between the positively charged functional groups $\left(\mathrm{NH}_{3}{ }^{+}\right)$of the support and negatively charged amino acid residues on the surface of GICA ( $\underline{\text { Fig.S2 }}$ ). 


\subsection{Continuous HFS production using packed bed reactor}

Due to the high cost of enzymes, packed-bed bioreactors filled with immobilized enzyme has gained special attention in the food industries because they are more economically. In order to investigate the performance of the adsorbed GICA in continuous HFS production, a packed bed reactor was settled as mentioned in Experimental Section and portrayed in Fig. S6. The bioreactor was operated at $0.03 \mathrm{~mL} / \mathrm{min}$ and $70^{\circ} \mathrm{C}$ using $50 \mathrm{~g} / \mathrm{L}$ of glucose as a feed solution. In our case, the residence time was calculated to be $33 \mathrm{~min}$. To determine the fructose yield during operation, different samples were taken from the outlet of the bioreactor at various times and analyzed by HPAEC-PAD. As shown in Fig. 5 , after $2 \mathrm{~h}$ of operation the bioconversion rate reached $46.5 \%$. Furthermore, a maximum fructose yield of $49.1 \%$ was observed after $48 \mathrm{~h}$ and this rate was maintained approximately constant during the eleven days of operation. Consequently, the productivity of the PBR was $45 \mathrm{~g} \mathrm{~L}^{-1} \mathrm{~h}-1$. The aforementioned results from lab-scale advocate that our adsorbed GICA on Sepabeads EC-HA could be an amenable candidate in continuous High Fructose syrup production at industrial level.

Compared to other previous studies that describing the application of immobilized GI's in continuous HFS production, our developed bioreactor based on Sepabeads-adsorbed GICA was more efficient and could be used for longer time. As depicted in Table S2, Rahmen et al., applied the commercial immobilized glucose isomerase from Streptomyces murinus (Sweetzyme, Novozymes) in continuous glucose isomerization using fixed bed reactor and the maximum isomerization percentage was $20.2 \%$ at $70^{\circ} \mathrm{C}$. In another study, the continuous production of HFS using immobilized glucose isomerase from Streptomyces murinus was assayed at $60^{\circ} \mathrm{C}$ and a bioconversion rate of $44 \%$ was attained after 10 days. 


\section{CONCLUSION}

The glucose isomerase GICA from Caldicoprobacter algeriensis was successfully adsorbed onto Sepabeads EC-HA using a straightforward method. The ionic adsorption strategy described in the present study is an attractive alternative method for GI immobilization due to its costeffectiveness, eco-friendless with no chemical reagent addition, high recovery of activity and good immobilization yield. Further, the biochemical comparative study between the two forms unveiled that our developed biocatalyst exhibited better thermo, $\mathrm{pH}$ and storage stability. Thanks to its high thermostability, the adsorbed GICA was applied in a continuous fixed bed reactor for High Fructose Syrup production during eleven days with approximately constant bioconversion isomerization rate of $49 \%$. The high efficiency of the immobilized GICA in HFS production denotes the effectiveness of our system. Nevertheless, further studies are required to optimize the process parameters of the developed bioreactor such as the temperature, substrate concentration, and feed flow rate.

\section{Conflit of interest:}

The authors declare that there is no conflict of interests regarding the publication of this paper.

\section{Ethical Statements}

This article does not contain any studies with human participants or animals performed by any of the authors.

\section{Acknowledgements}

This work was supported by the Tunisian Ministry of Higher Education and Scientific Research and Technology (contract program LBMIE-CBS, code: LR15CBS06), University of Sfax (doctoral school of FSS) and the Spanish Ministry of Economy and Competitiveness (Grant BIO201676601-C3-1-R).

The authors would like to express their gratitude to the all member of applied biocatalyst group especially Noa Míguez and Joselu González Alfonso for their constructive discussions, suggestions and valuable help. Authors are thankful to SIDI-UAM service for providing SEM analysis. Special thanks are also due to Prof. Miguel Alcalde and his research group for their valuable help. 


\section{REFERENCES:}

Abbaszadeh, M., \& Hejazi, P. (2019). Metal affinity immobilization of cellulase on Fe304 nanoparticles with copper as ligand for biocatalytic applications. Food chemistry, 290,4755. https://doi.org/10.1016/i.foodchem.2019.03.117

Ali, S., Zafar, W., Shafiq, S., \& Manzoor, M. (2017). Enzymes immobilization: An overview of techniques, support materials and its applications. International journal of scientific \& technology research, 6, 64. ISSN 2277-8616

Alonso, N., López-Gallego, F., Betancor, L., Hidalgo, A., Mateo, C., Guisan, J. M., \& FernandezLafuente, R. (2005). Immobilization and stabilization of glutaryl acylase on aminated sepabeads supports by the glutaraldehyde crosslinking method. Journal of Molecular Catalysis B: Enzymatic, 35(1-3), 57-61. https://doi.org/10.1016/i.molcatb.2005.05.007

Araya, E., Urrutia, P., Romero, O., Illanes, A., \& Wilson, L. (2019). Design of combined crosslinked enzyme aggregates (combi-CLEAs) of $\beta$-galactosidase and glucose isomerase for the one-pot production of fructose syrup from lactose. Food chemistry, 288, 102-107. https://doi.org/10.1016/i.foodchem.2019.02.024

Bayraktar, H., Serilmez, M., Karkaş, T., Çelem, E. B., \& Önal, S. (2011). Immobilization and stabilization of $\alpha$-galactosidase on Sepabeads EC-EA and EC-HA. International journal of biological macromolecules, 49(4),

855-860.

https://doi.org/10.1016/j.ijbiomac.2011.08.009

Bedade, D. K., Sutar, Y. B., \& Singhal, R. S. (2019). Chitosan coated calcium alginate beads for covalent immobilization of acrylamidase: Process parameters and removal of acrylamide from coffee. Food chemistry, 275, 95-104. https://doi.org/10.1016/j.foodchem.2018.09.090

Bradford, M. M. (1976). A rapid and sensitive method for the quantitation of microgram quantities of protein utilizing the principle of protein-dye binding. Analytical biochemistry, 72(1-2), 248-254.

Bryjak, J., \& Trochimczuk, A. W. (2006). Immobilization of lipase and penicillin acylase on hydrophobic acrylic carriers. Enzyme and microbial technology, 39(4), 573-578. https://doi.org/10.1016/j.enzmictec.2005.11.013

Chen, W., \& Anderson, A. (1979). Purification, immobilization, and some properties of glucose isomerase from Streptomyces flavogriseus. Appl. Environ. Microbiol., 38(6), 1111-1119.

Chopda, V. R., Nagula, K. N., Bhand, D. V., \& Pandit, A. B. (2014). Studying the effect of nature of glass surface on immobilization of glucose isomerase. Biocatalysis and Agricultural Biotechnology, 3(3), 86-89. https://doi.org/10.1016/i.bcab.2014.01.001

Dehkordi, A. M., Tehrany, M. S., \& Safari, I. (2009). Kinetics of glucose isomerization to fructose by immobilized glucose isomerase (Sweetzyme IT). Industrial \& Engineering Chemistry Research, 48(7), 3271-3278. https://doi.org/10.1021/ie800400b

Demir, T., \& Önal, S. (2018). Bioaffinity immobilization and characterization of $\alpha$-galactosidase on aminophenylboronicacid derivatized chitosan and Sepabeads EC-EA. LWT, 90, 547555. https://doi.org/10.1016/j.lwt.2017.12.073

Demirel, G., Özçetin, G., Şahin, F., Tümtürk, H., Aksoy, S., \& Hasirci, N. (2006). Semiinterpenetrating polymer networks (IPNs) for entrapment of glucose isomerase. 
Reactive and Functional Polymers, 66(4), 389-394. https://doi.org/10.1016/j.reactfunctpolym.2005.08.015

Desai, S., Gachhi, D., \& Hungund, B. (2016). Glucose isomerising Enzymes..

DiCosimo, R., McAuliffe, J., Poulose, A. J., \& Bohlmann, G. (2013). Industrial use of immobilized enzymes. Chemical Society Reviews, 42(15), 6437-6474. https://doi.org/ $10.1039 / \mathrm{c} 3 \mathrm{cs} 35506 \mathrm{c}$

Drout, R. J., Robison, L., \& Farha, O. K. (2019). Catalytic applications of enzymes encapsulated in metal-organic frameworks. Coordination Chemistry Reviews, 381, 151-160. https://doi.org/10.1016/j.ccr.2018.11.009

Fernandes, P. (2010). Enzymes in food processing: a condensed overview on strategies for better biocatalysts. Enzyme research, 2010. https://doi.org/10.4061/2010/862537

Fernandez-Arrojo, L., Rodriguez-Colinas, B., Gutierrez-Alonso, P., Fernandez-Lobato, M., Alcalde, M., Ballesteros, A. O., \& Plou, F. J. (2013). Dried alginate-entrapped enzymes (DALGEEs) and their application to the production of fructooligosaccharides. Process Biochemistry, 48(4), 677-682. https://doi.org/10.1016/j.procbio.2013.02.015

Fernandez-Arrojo, L., Santos-Moriano, P., Rodriguez-Colinas, B., Ballesteros, A. O., \& Plou, F. J. (2015). Micro-scale procedure for enzyme immobilization screening and operational stability assays. Biotechnology letters, 37(8), 1593-1600. https://doi.org/10.1007/s10529-015-1835-z.

Ge, Y., Zhou, H., Kong, W., Tong, Y., Wang, S., \& Li, W. (1998). Immobilization of glucose isomerase and its application in continuous production of high fructose syrup. Applied biochemistry and biotechnology, 69(3), 203-215. https://doi.org/10.1007/BF02788814

Hilterhaus, L., Minow, B., Müller, J., Berheide, M., Quitmann, H., Katzer, M., Thum, O., Antranikian, G., Zeng, A., \& Liese, A. (2008). Practical application of different enzymes immobilized on sepabeads. Bioprocess and biosystems engineering, 31(3), 163-171. https://doi.org/10.1007/s00449-008-0199-3

Jesionowski, T., Zdarta, J., \& Krajewska, B. (2014). Enzyme immobilization by adsorption: A review. Adsorption, 20(5-6), 801-821. https://doi.org/10.1007/s10450-014-9623-y

Jia, D.-X., Wang, T., Liu, Z.-J., Jin, L.-Q., Li, J.-J., Liao, C.-J., Chen, D.-S., \& Zheng, Y.-G. (2018). Whole cell immobilization of refractory glucose isomerase using tris (hydroxymethyl) phosphine as crosslinker for preparation of high fructose corn syrup at elevated temperature. Journal of bioscience and bioengineering, 126(2), 176-182. https://doi.org/ 10.1016/i.jbiosc.2018.03.001.

Jin, L.-Q., Xu, Q., Liu, Z.-Q., Jia, D.-X., Liao, C.-J., Chen, D.-S., \& Zheng, Y.-G. (2017). Immobilization of recombinant glucose isomerase for efficient production of high fructose corn syrup. Applied biochemistry and biotechnology, 183(1), 293-306. https://doi.org/10.1007/s12010-017-2445-0

Kamal, H., Hegazy, E.-S. A., Sharada, H. M., Abd elhalim, S. A., Lotfy, S., \& Mohamed, R. D. (2014). Immobilization of glucose isomerase onto radiation synthesized $\mathrm{P}$ (AA-co-AMPS) hydrogel and its application. Journal of Radiation Research and Applied Sciences, 7(2), 154-162. https://doi.org/10.1016/j.jrras.2014.02.001 
Khalilpour, R., \& Roostaazad, R. (2008). Development and verification of a model to describe an immobilized glucose isomerase packed bed bioreactor. Biochemical Engineering Journal, 40(2), 328-336. https://doi.org/10.1016/j.bej.2008.01.017

Kolev, N. (2006). Packed Bed Columns.

Kovalenko, G., Perminova, L., Chuenko, T., Sapunova, L., Shlyakhotko, E., \& Lobanok, A. (2011). Immobilization of a recombinant strain producing glucose isomerase inside $\mathrm{SiO} 2$ xerogel and properties of prepared biocatalysts. Applied biochemistry and microbiology, 47(2), 151-157.https://doi.org/10.1134/S0003683811020074

Míguez, N., Gimeno-Pérez, M., Fernández-Polo, D., Cervantes, F., Ballesteros, A., FernándezLobato, M., Ribeiro, M., \& Plou, F. (2018). Immobilization of the $\beta$-fructofuranosidase from Xanthophyllomyces dendrorhous by Entrapment in Polyvinyl Alcohol and Its Application to Neo-Fructo oligosaccharides Production. Catalysts, 8(5), 201. https://doi.org/10.3390/catal8050201

Mohamad, N. R., Marzuki, N. H. C., Buang, N. A., Huyop, F., \& Wahab, R. A. (2015). An overview of technologies for immobilization of enzymes and surface analysis techniques for immobilized enzymes. Biotechnology \& Biotechnological Equipment, 29(2), 205-220. https://doi.org/10.1080/13102818.2015.1008192

Neifar, S., Hlima, H. B., Mhiri, S., Mezghani, M., Bouacem, K., Ibrahim, A. H., Jaouadi, B., BouananeDarenfed, A., \& Bejar, S. (2019). A novel thermostable and efficient Class II glucose isomerase from the thermophilic Caldicoprobacter algeriensis: Biochemical characterization, molecular investigation, and application in High Fructose Syrup production. International journal of biological macromolecules, 129, 31-40. https://doi.org/10.1016/j.ijbiomac.2019.01.150.

Prlainović, N. Ž., Knežević-Jugović, Z. D., Mijin, D. Ž., \& Bezbradica, D. I. (2011). Immobilization of lipase from Candida rugosa on Sepabeads $\AA$ : the effect of lipase oxidation by periodates. Bioprocess and biosystems engineering, 34(7), 803-810. https://doi.org/10.1007/s00449-011-0530-2

Rahman, N. A., Hussain, M., \& Jahim, J. M. (2012). Production of fructose using recycle fixed-bed reactor and batch bioreactor. Journal of Food, Agriculture \& Environment, 10(2), 268273. ISSN: $1459-0263$

Rios, N. S., Pinheiro, B. B., Pinheiro, M. P., Bezerra, R. M., dos Santos, J. C. S., \& Gonçalves, L. R. B. (2018). Biotechnological potential of lipases from Pseudomonas: sources, properties and applications. Process Biochemistry. https://doi.org/10.1016/j.procbio.2018.09.003

Saponji, S., Kneevi-Jugovi, Z. D., Bezbradica, D. I., Zuza, M. G., Saied, O. A., Boskovi-Vragolovi, N., \& Mijin, D. Z. (2010). Use of Candida rugosa lipase immobilized on sepabeads for the amyl caprylate synthesis: Batch and fluidized bed reactor study. Electronic Journal of Biotechnology, 13(6), 12-13. https://doi.org/ 10.2225

Shakoor, S., Singh, G., \& Singh, M. (2018). Glucose Isomerase Production and Its Application In Various Field. https://doi.org/10.32628/IJSRST1845102.

Singh, R., Chauhan, K., Pandey, A., \& Larroche, C. (2018). Biocatalytic strategies for the production of high fructose syrup from inulin. Bioresource technology, 260, 395-403. https://doi.org/10.1016/j.biortech.2018.03.127 
Suryawanshi, R. K., Jana, U. K., Prajapati, B. P., \& Kango, N. (2019). Immobilization of Aspergillus quadrilineatus RSNK-1 multi-enzymatic system for fruit juice treatment and mannooligosaccharide generation. Food chemistry, 289, 95-102. https://doi.org/10.1016/i.foodchem.2019.03.035.

Torres, P., \& Batista-Viera, F. (2012). Improved biocatalysts based on Bacillus circulans $\beta$ galactosidase immobilized onto epoxy-activated acrylic supports: Applications in whey processing. Journal of Molecular Catalysis B: Enzymatic, 83, 57-64. https://doi.org/10.1016/j.molcatb.2012.07.004

Tükel, S. S., \& Alagöz, D. (2008). Catalytic efficiency of immobilized glucose isomerase in isomerization of glucose to fructose. Food chemistry, 111(3), 658-662. https://doi.org/10.1016/j.jrras.2014.02.001

Tumturk, H., Demirel, G., Altinok, H., Aksoy, S., \& Hasirci, N. (2008). Immobilization of glucose isomerase in surface-modified alginate gel beads. Journal of food biochemistry, 32(2), 234-246. https://doi.org/10.1111/i.1745-4514.2008.00171.x

White, J. S. (2014). Sucrose, HFCS, and fructose: history, manufacture, composition, applications, and production. In Fructose, high fructose corn syrup, sucrose and health, (pp. 13-33): Springer. https://doi.org/10.1007/978-1-4899-8077-9 2.

Zargaraan, A., Kamaliroosta, L., Yaghoubi, A. S., \& Mirmoghtadaie, L. (2016). Effect of substitution of sugar by high fructose corn syrup on the physicochemical properties of bakery and dairy products: a review. Nutrition and Food Sciences Research, 3(4), 3-11. https://doi.org/10.18869/acadpub.nfsr.3.4.3

Zhao, H., Cui, Q., Shah, V., Xu, J., \& Wang, T. (2016). Enhancement of glucose isomerase activity by immobilizing on silica/chitosan hybrid microspheres. Journal of Molecular Catalysis B: Enzymatic, 126, 18-23. https://doi.org/10.1016/i.molcatb.2016.01.013

Zhong, N., Chen, W., Liu, L., \& Chen, H. (2019). Immobilization of Rhizomucor miehei lipase onto the organic functionalized SBA-15: Their enzymatic properties and glycerolysis efficiencies for diacylglycerols production. Food chemistry, 271, 739-746. https://doi.org/ 10.1016/j.foodchem.2018.07.185 


\section{FIGURE CAPTIONS}

Figure 1: Scanning electron microscopy (SEM) micrographs of Sepabeads EC-HA on different sizes scales: (A) $75 \mathrm{x}$; (B) $600 \mathrm{x}$; (C) $50000 \mathrm{x}$.

Figure 2: Thermostability profile of free and immobilized GICA at different temperature in the presence of $0.5 \mathrm{mM} \mathrm{Co}^{2+}$ and $20 \mathrm{mM} \mathrm{Mg}^{2+}$ : (A): at $85^{\circ} \mathrm{C}$; (B): at $80^{\circ} \mathrm{C}$; (C): $75^{\circ} \mathrm{C}$; (D): $70^{\circ} \mathrm{C}$. The non-pre-incubated enzyme activity was defined as $100 \%$. Error bars represent the standard deviation from three separated assays.

Figure 3: Impact of $\mathrm{pH}$ on enzyme activity of free and immobilized enzyme at different $\mathrm{pH}$ ranging from 5 to 10 . Activity at optimal $\mathrm{pH}$ was defined as $100 \%$. Error bars represent the standard deviation from three separated assays.

Figure 4: Operational stability of the biocatalyst GICA under batch reaction at $85^{\circ} \mathrm{C}$. Reaction conditions per cycle: $0.8 \mathrm{mM}$ glucose, $0.5 \mathrm{mM} \mathrm{Co}^{2+}$ and $20 \mathrm{mM} \mathrm{Mg}^{2+}$ in $100 \mathrm{mM}$ MOPS buffer $\mathrm{pH}$ $7,3 \mathrm{~h}$ reaction per cycle.

Figure 5: Continuous HFS production using packed bed reactor at $70^{\circ} \mathrm{C}$ under 11 days of operation. The flow of the feeding solution $\left(50 \mathrm{~g} / \mathrm{L}\right.$ glucose, $20 \mathrm{mM} \mathrm{MgCl} 2,0.5 \mathrm{mM} \mathrm{CoCl}_{2}$ in 0.1 M MOPS buffer $\mathrm{pH}$ 7.0) was maintained at $0.03 \mathrm{~mL} \mathrm{~min}^{-1}$. 
Figure 1

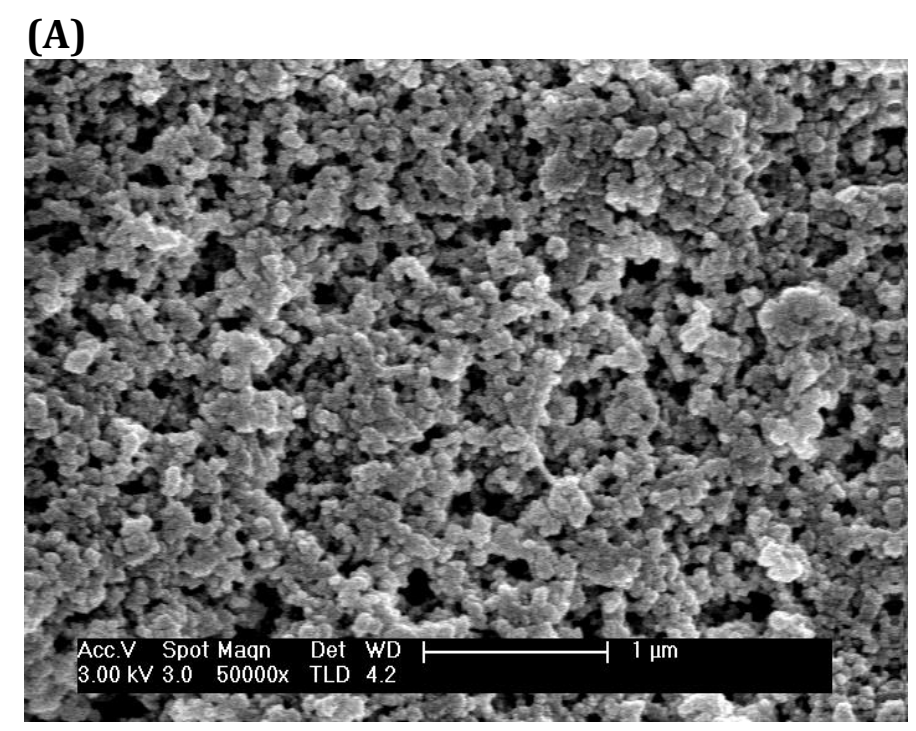

(B)

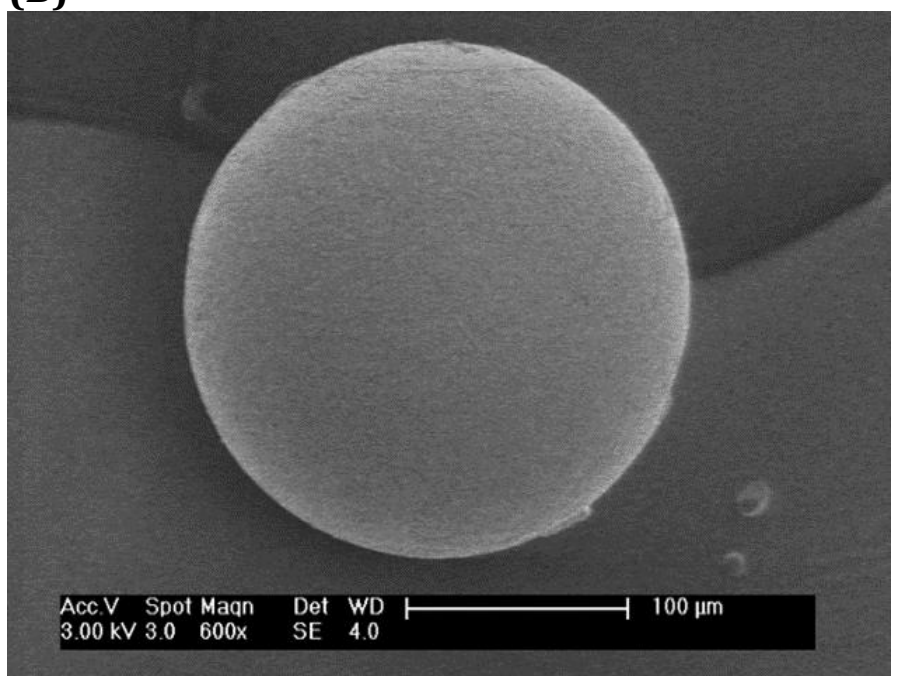

(C)

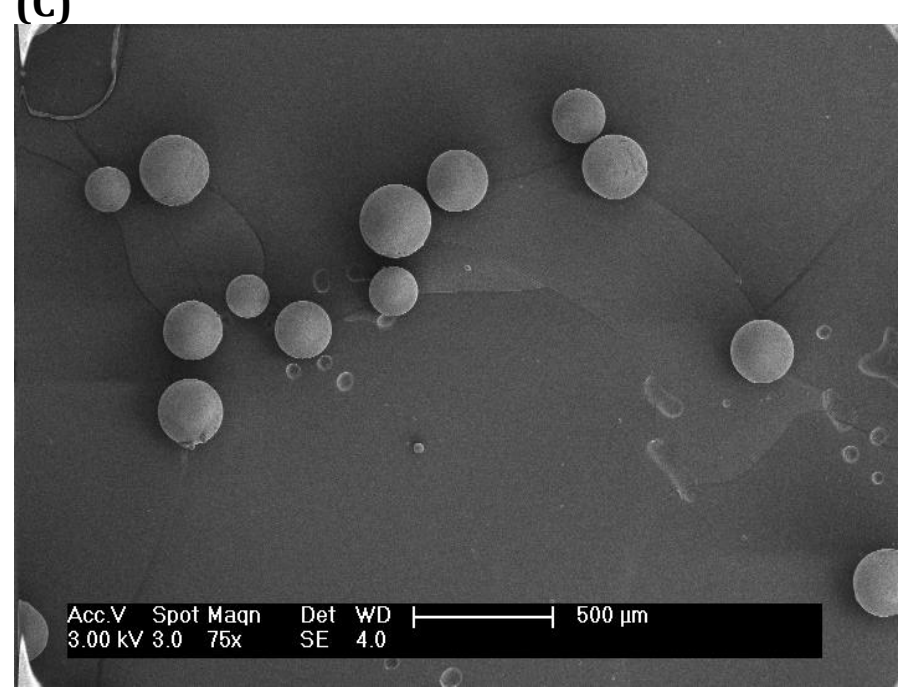

Go back to Fig 1 
Figure 2

Go back to Fig 2

(A)

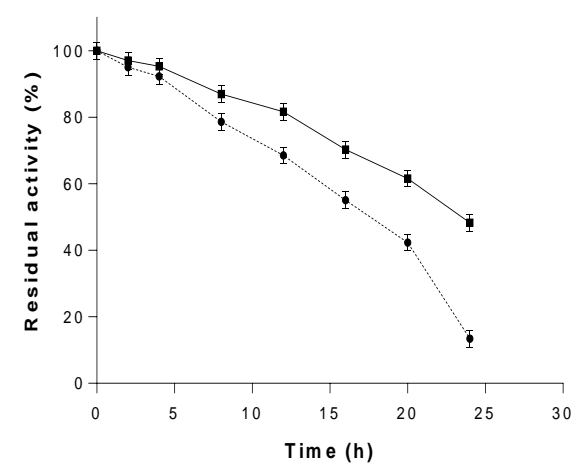

(C)

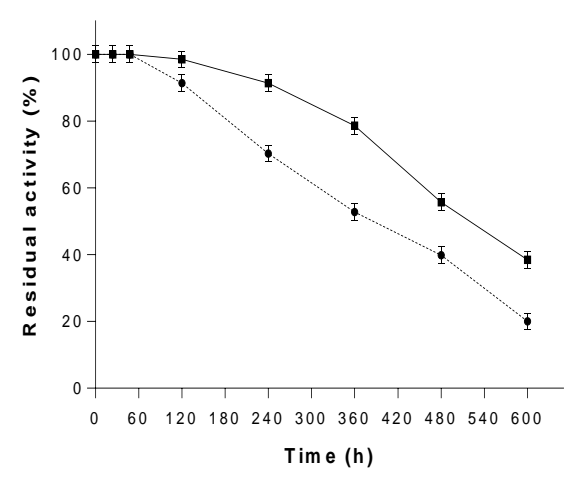

(B)

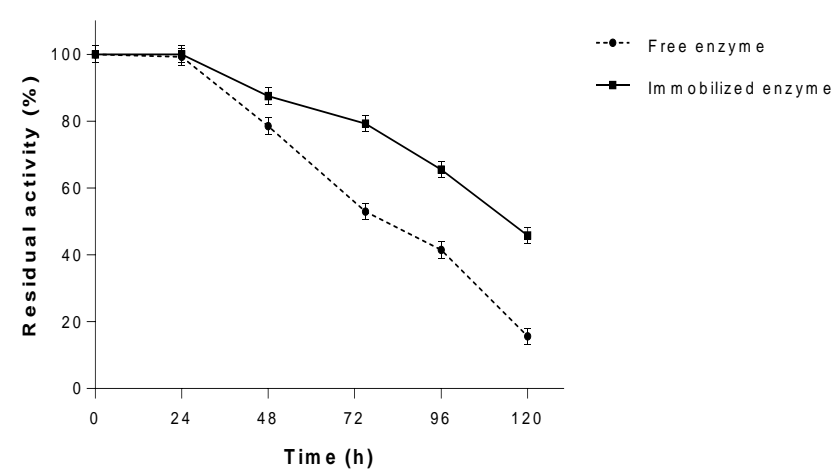

(D)

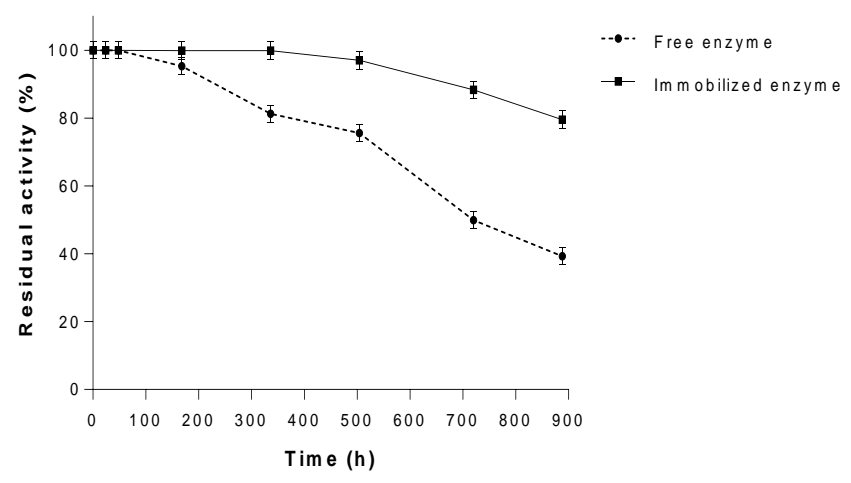


Figure 3

Go back to Fig 3

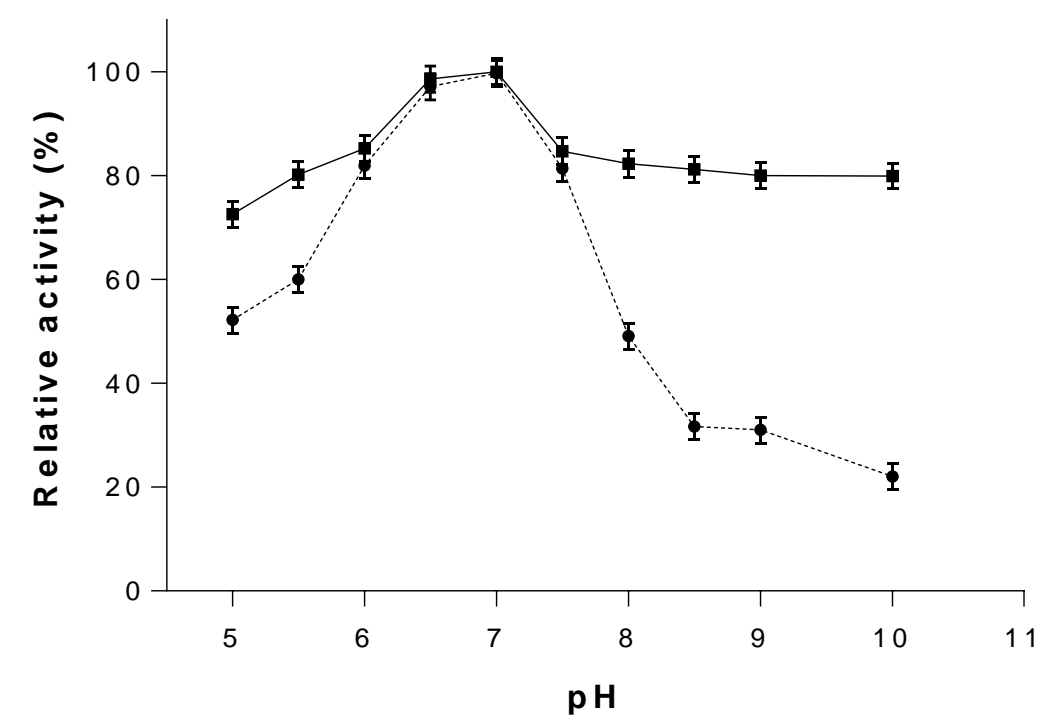

Figure 4

Go back to Fig 4

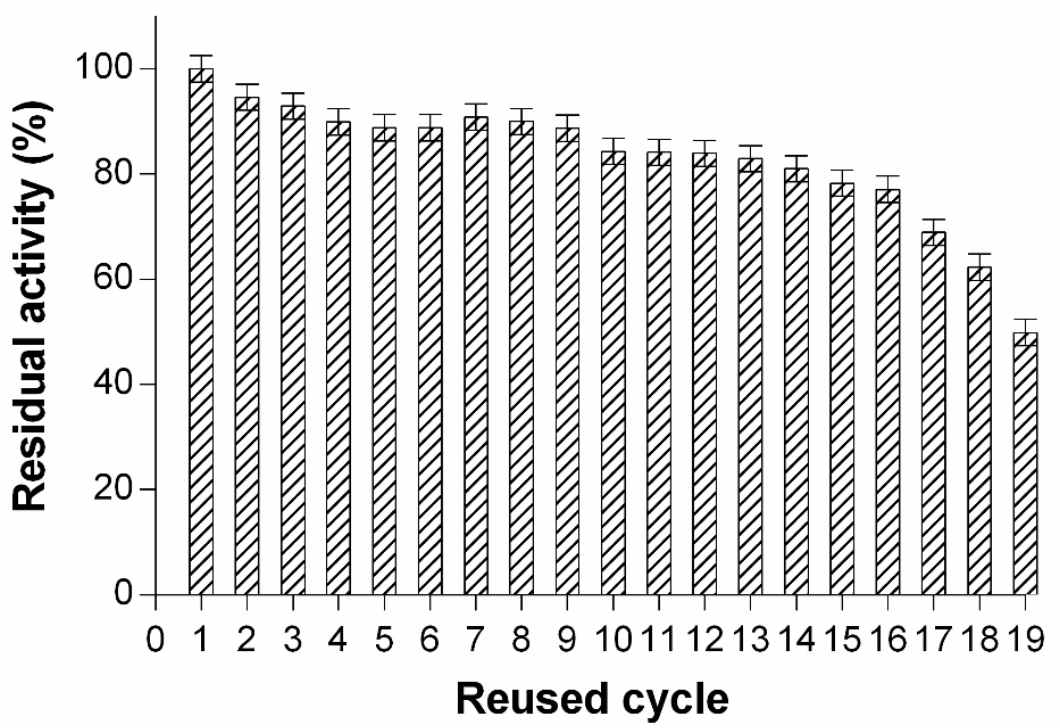


Figure 5

Go back to Fig 5

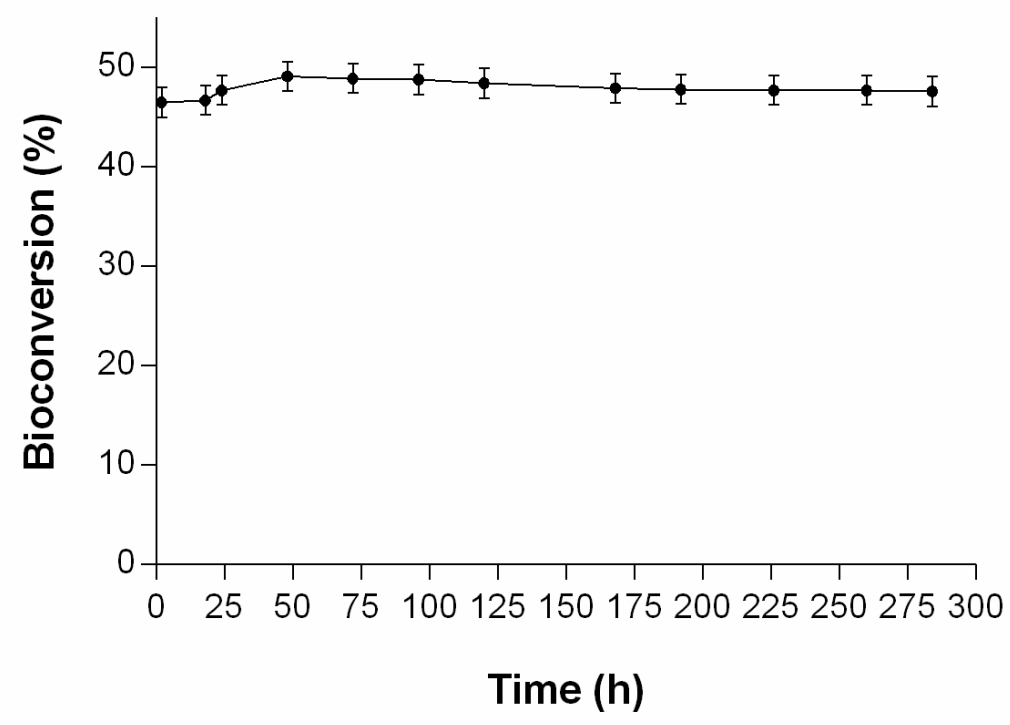


Table 1: Summary of the main immobilization parameters with the three supports under the optimal conditions for each carrier.

\begin{tabular}{|c|c|c|c|c|c|}
\hline \multirow{2}{*}{ Support } & \multirow{2}{*}{$\begin{array}{l}\text { Total initial } \\
\text { activity } \\
\text { (U) }\end{array}$} & \multirow{2}{*}{$\begin{array}{l}\text { Amount of } \\
\text { carrier }\end{array}$} & \multirow{2}{*}{$\begin{array}{l}\text { Recovered } \\
\text { activity } \\
(\%)^{\mathbf{b}}\end{array}$} & \multicolumn{2}{|c|}{ Activity of the biocatalyst (U/g) } \\
\hline & & & & Theoretical b & Apparent ${ }^{c}$ \\
\hline $\begin{array}{l}\text { Glyoxyl } \\
\text { agarose }\end{array}$ & 1.81 & $\begin{array}{l}300 \mu \mathrm{L}(100 \\
\mathrm{mg})\end{array}$ & 22.1 & 4.0 & 0.93 \\
\hline $\begin{array}{l}\text { Sepabeads EC- } \\
\text { EA }\end{array}$ & 5.42 & $250 \mathrm{mg}$ & 82.2 & 17.8 & 10.2 \\
\hline $\begin{array}{l}\text { Sepabeads EC- } \\
\text { HA }\end{array}$ & 5.42 & $250 \mathrm{mg}$ & 88.7 & 19.2 & 12.5 \\
\hline
\end{tabular}

a Measured by HPAEC-PAD

b Calculated by subtracting the initial activity and the activity in the filtrate and washings

c Measured activity

Go back to Table 1 


\section{APPENDIX. SUPPLEMENTARY DATA}

The following are the Supplementary data to this article:

Figures:

Figure S1: Schematic illustration of the operational stability process under batch reaction.

Figure S2: Surface presentation of the 3Dmodel of GICA showing the amino acid residues: Serine, tyrosine and threonine (colored in red) that could participate in the ionic interaction with the functional group $\left(\mathrm{NH}_{3}{ }^{+}\right)$of Sepabeads support and highlighting the active site with yellow circle.

Figure S3: Electrostatic surface presentation of GIAG showing the negatively and positively charged residues in red and blue color, respectively.

Figure S4: Effect of temperature on free and immobilized enzyme activity in the presence of $0.5 \mathrm{mM} \mathrm{Co}^{2+}$ and $20 \mathrm{mM} \mathrm{Mg}^{2+}$. Activity at optimal temperature was defined as $100 \%$. Error bars represent the standard deviation from three separated assays.

Figure S5: $\mathrm{pH}$ stability profile of the free and immobilized enzyme at $4^{\circ} \mathrm{C}$ at different $\mathrm{pH}$ : (A): at $\mathrm{pH}$ 6; (B): pH 6.5 and (C): at pH 7. The non-pre-incubated enzyme activity was defined as $100 \%$. Error bars represent the standard deviation from three separated experiments.

Figure S6: Schematic diagram of Continuous HFS production using packed bed reactor. 
Figure S1

Go back to Fig S1

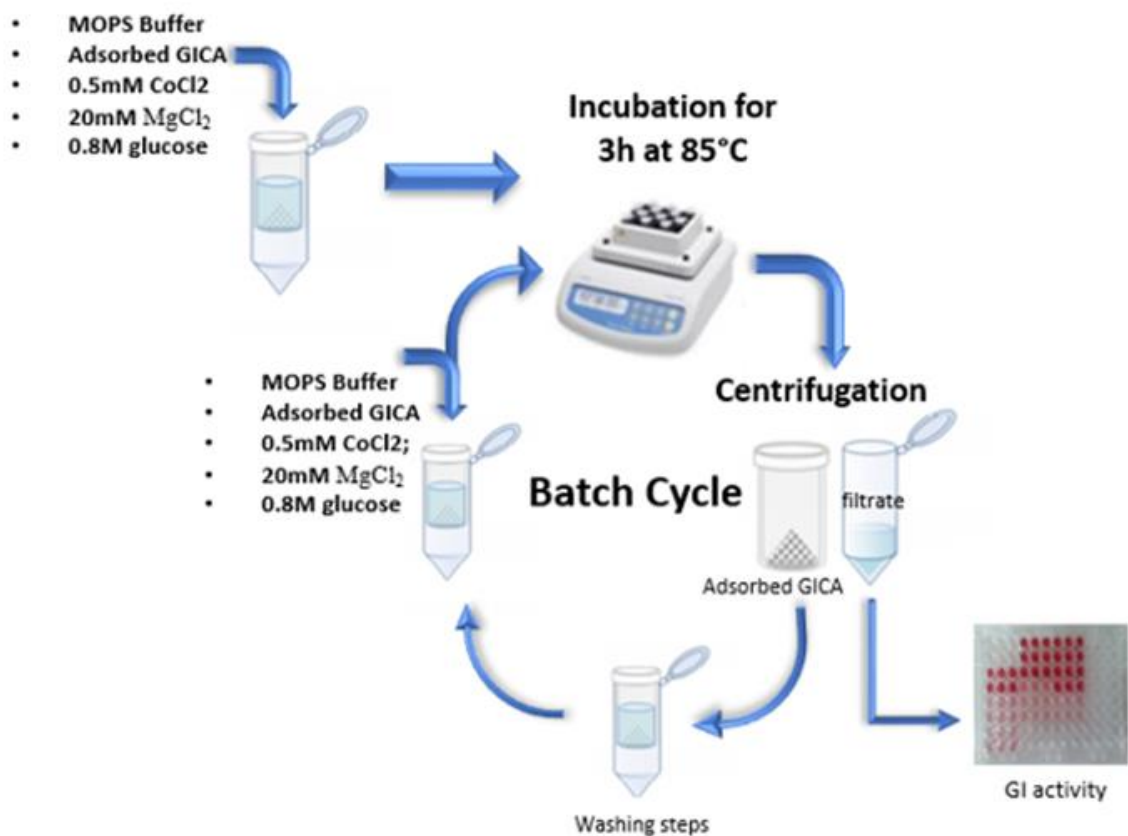

Figure S2

Go back to Fig S2(irst mention) (
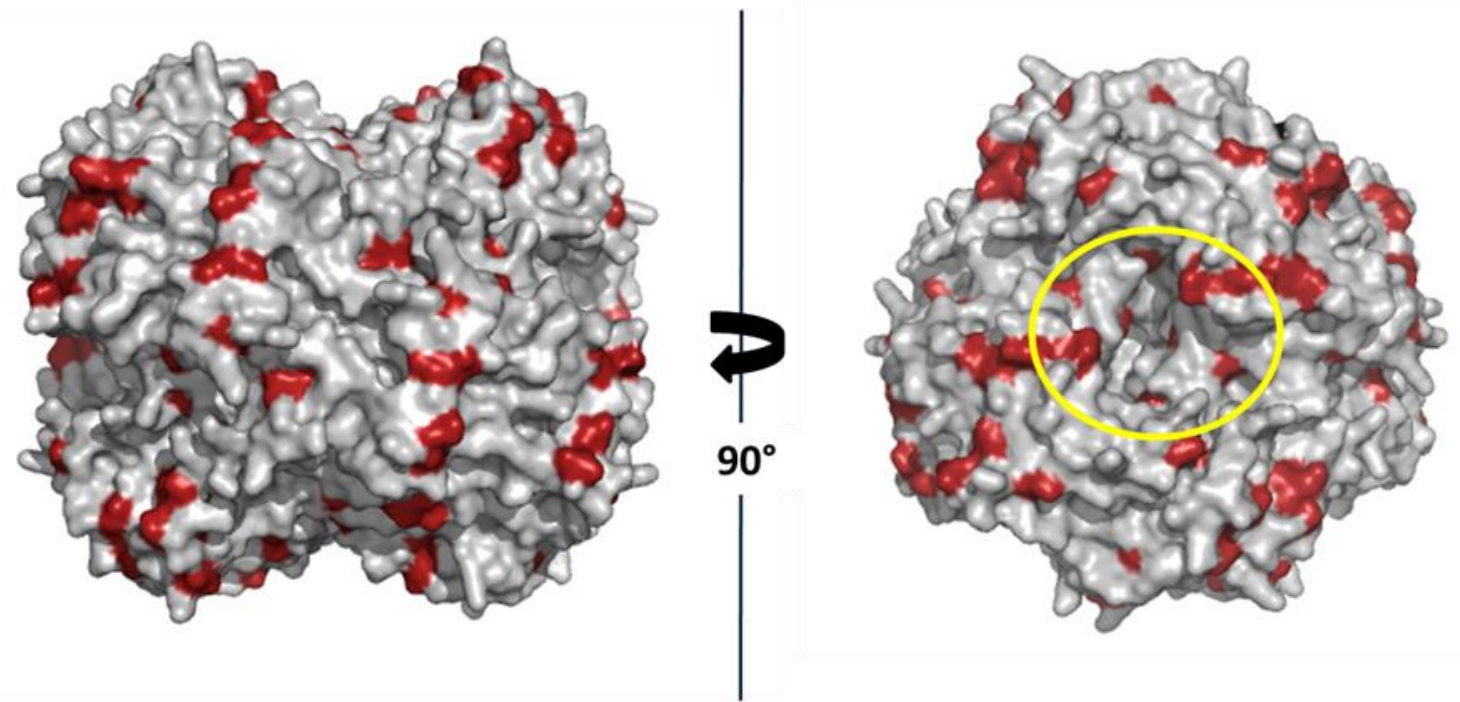


\section{Figure S3}

Go back to Fig S3
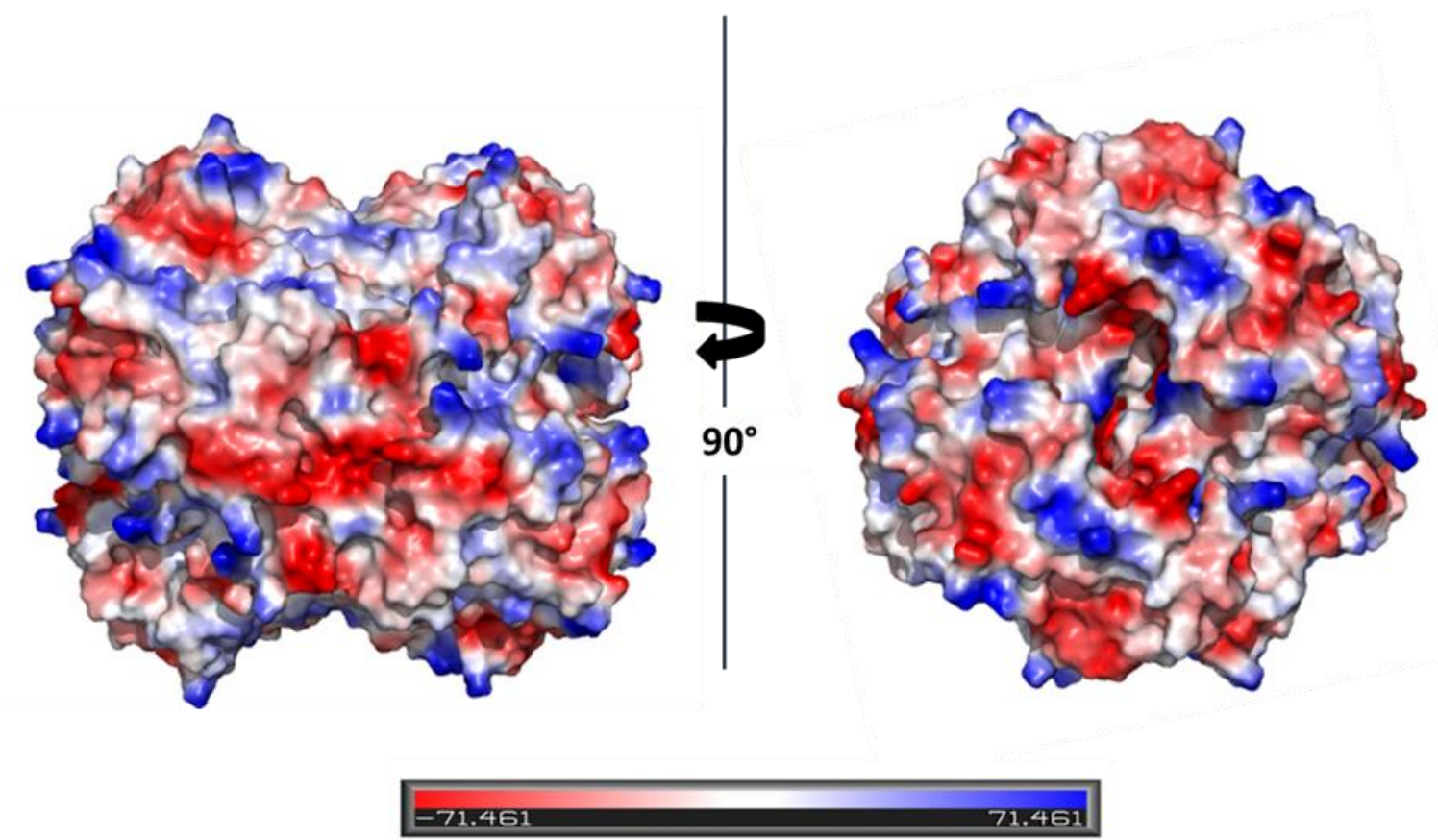

\section{Figure S4}

Go back to Fig S4

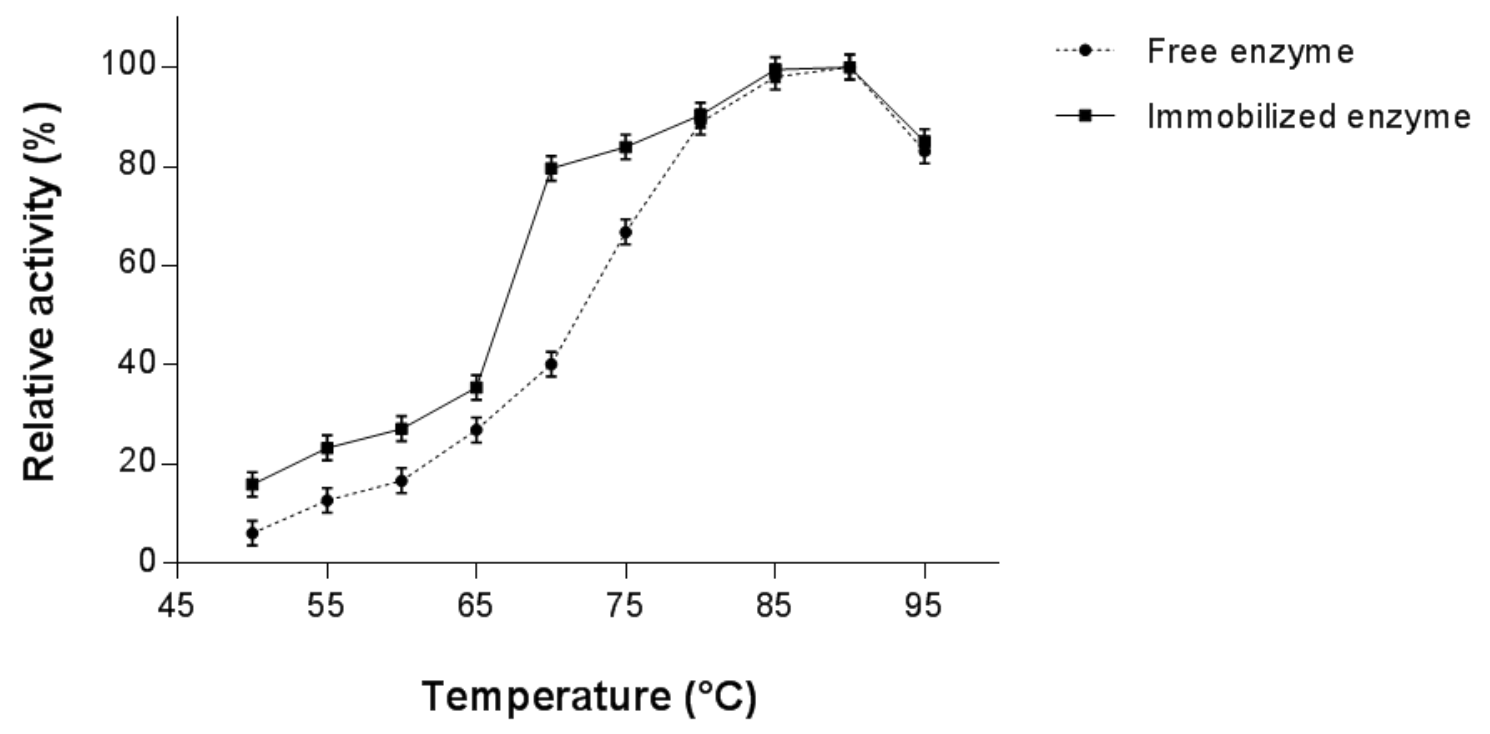


Figure S5

Go back to Fig S5

(A)

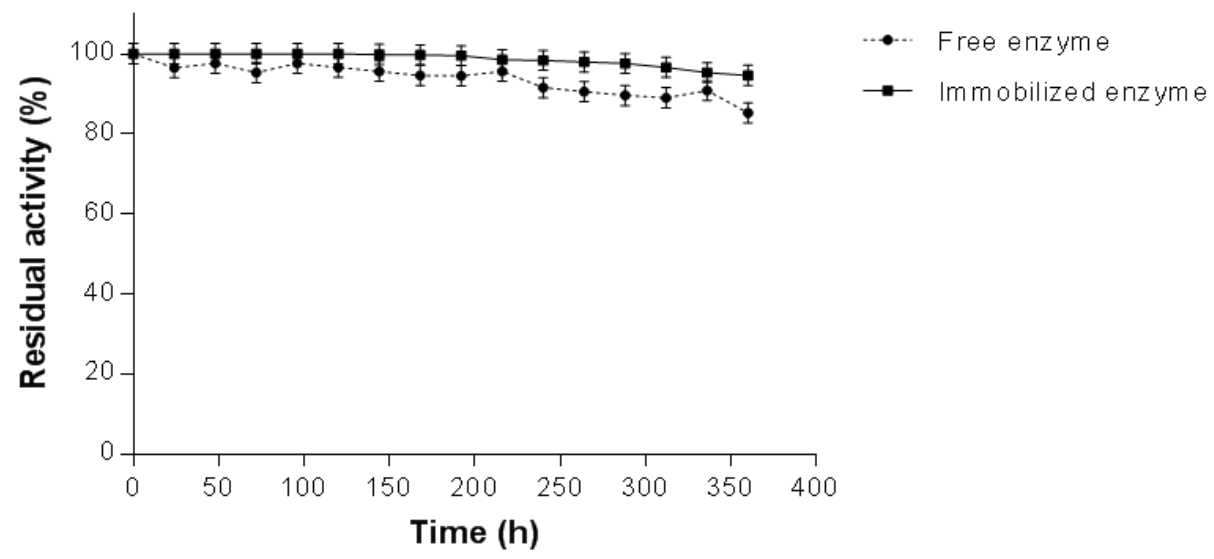

(B)

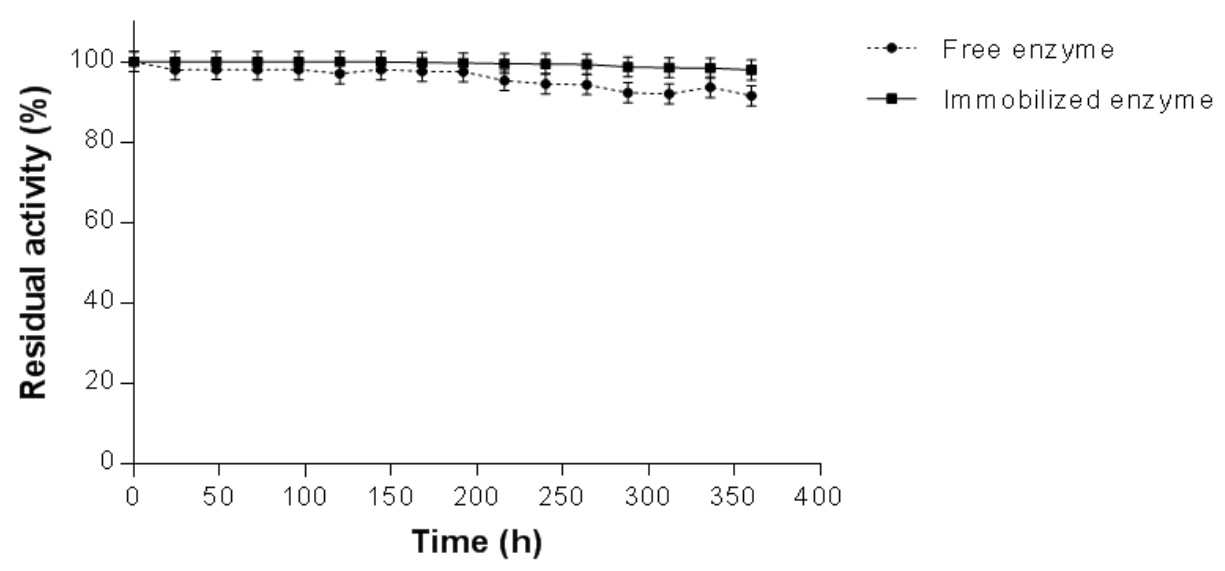

(C)

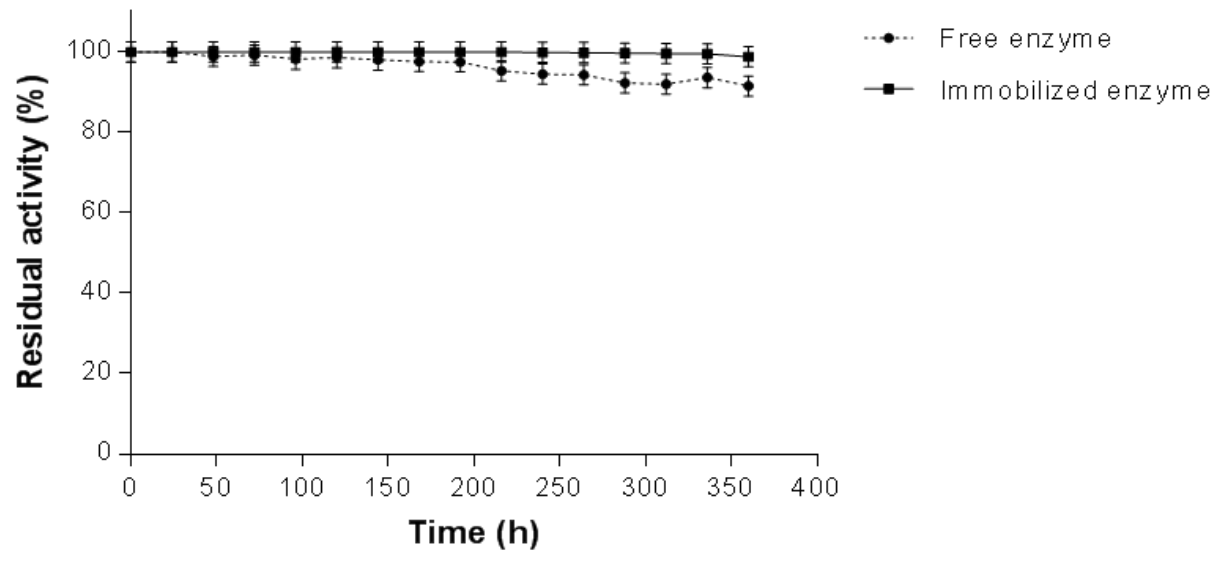


Figure S6

Go back to Fig S6

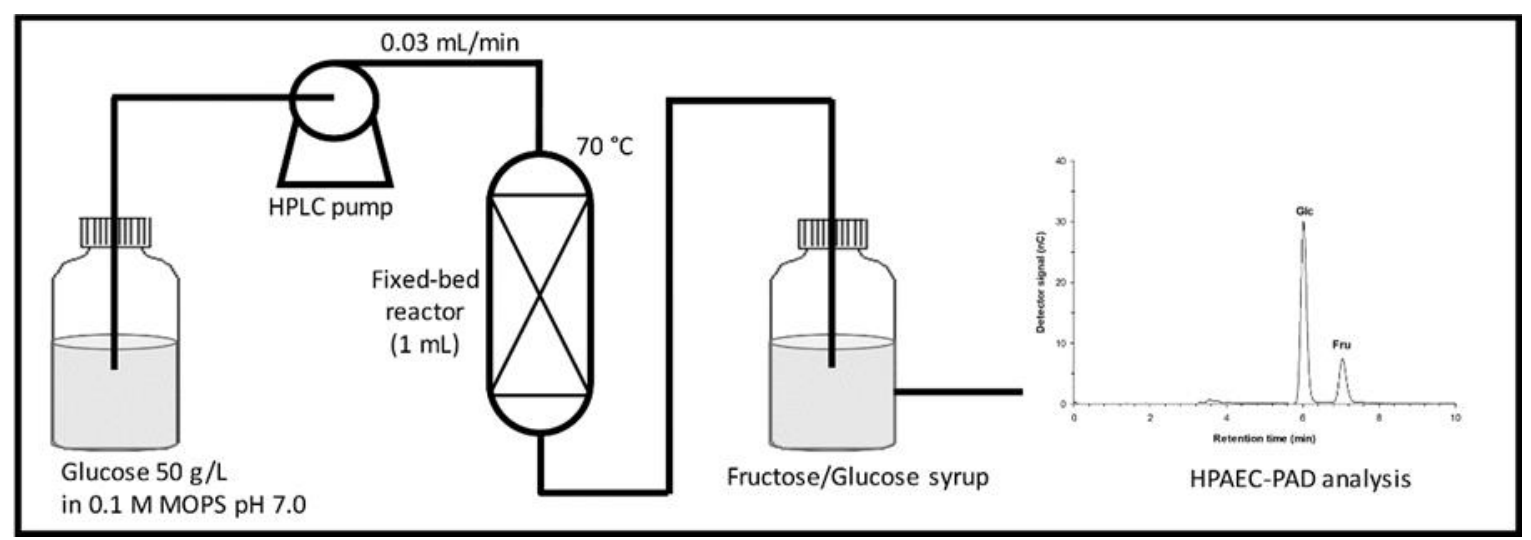




\section{TABLES}

Table S1: Comparison of operational stability from different immobilized GI's using different supports

\begin{tabular}{|c|c|c|c|c|c|c|c|}
\hline $\begin{array}{l}\text { Microorganism } \\
\text { S }\end{array}$ & $\begin{array}{l}\text { Support of } \\
\text { immobilizatio } \\
n\end{array}$ & $\mathbf{p H}$ & $\begin{array}{l}\text { Temperatu } \\
\text { re }\left({ }^{\circ} \mathrm{C}\right)\end{array}$ & $\begin{array}{l}\text { Numbe } \\
\mathbf{r} \text { of } \\
\text { cycles }\end{array}$ & $\begin{array}{l}\text { Reaction } \\
\text { time/cyc } \\
\text { le (min) } \\
\end{array}$ & $\begin{array}{l}\text { Remaining } \\
\text { activity } \\
(\%)\end{array}$ & References \\
\hline $\begin{array}{l}\text { Caldicoprobacter } \\
\text { algeriensis }\end{array}$ & $\begin{array}{l}\text { Adsorption on } \\
\text { Sepabeads EC- } \\
\text { HA }\end{array}$ & 7.0 & 70 & 15 & 180 & 89 & (this study) \\
\hline Not described & $\begin{array}{l}\text { non-porous } \\
\text { glass surfaces } \\
\text { using } \\
\text { polyethyleneim } \\
\text { ine as activator }\end{array}$ & 7.5 & 70 & 20 & 60 & 89 & $\begin{array}{l}\text { (Chopda, } \\
\text { Nagula, } \\
\text { Bhand, \& } \\
\text { Pandit, } \\
\text { 2014) }\end{array}$ \\
\hline $\begin{array}{l}\text { Streptomyces } \\
\text { rubiginosus }\end{array}$ & $\begin{array}{l}\text { Silica/chitosan } \\
\text { core-shell } \\
\text { hybrid } \\
\text { microspheres }\end{array}$ & 7.5 & 70 & 15 & 10 & 90 & $\begin{array}{l}\text { (Zhao, Cui, } \\
\text { Shah, Xu, \& } \\
\text { Wang, } \\
\text { 2016) }\end{array}$ \\
\hline Not described & $\begin{array}{l}\text { Poly (acrylic } \\
\text { acid-co-2- } \\
\text { Acrylamido 2- } \\
\text { methyl } \\
\text { Propane } \\
\text { sulfonic acid) }\end{array}$ & 7.5 & 65 & 15 & 80 & 81 & $\begin{array}{l}\text { (Demirel, } \\
\text { Özçetin, } \\
\text { Şahin, } \\
\text { Tümtürk, } \\
\text { Aksoy, \& } \\
\text { Hasirci, } \\
\text { 2006) }\end{array}$ \\
\hline $\begin{array}{l}\text { Streptomyces } \\
\text { rubiginosus }\end{array}$ & $\begin{array}{l}\text { Eupergit C } 250 \\
\text { L }\end{array}$ & 7.0 & 60 & 18 & 30 & 85 & $\begin{array}{l}\text { (Tükel \& } \\
\text { Alagöz, } \\
\text { 2008) }\end{array}$ \\
\hline Not described & CLEAs C & 7.5 & 45 & 5 & 10 & $\begin{array}{l}\text { The mass } \\
\text { loss of the } \\
\text { catalyst } \\
\text { between } \\
\text { batches was } \\
\text { negligible. }\end{array}$ & $\begin{array}{l}\text { (Araya, } \\
\text { Urrutia, } \\
\text { Romero, } \\
\text { Illanes, \& } \\
\text { Wilson, } \\
\text { 2019) }\end{array}$ \\
\hline
\end{tabular}


Table S2: Comparison of fructose conversion by different immobilized GI's using Packed-Bed Reactor

\begin{tabular}{|c|c|c|c|}
\hline Microorganisms & Reaction Conditions & $\begin{array}{l}\text { Conversion } \\
(\%)\end{array}$ & References \\
\hline Caldicoprobacter algeriensis & $\begin{array}{l}\text { Temperature } 70^{\circ} \mathrm{C}, \mathrm{pH} 7 \text {, Flow rate } \\
0.03 \mathrm{~mL} / \mathrm{min}\end{array}$ & 49 & (this study) \\
\hline $\begin{array}{l}\text { Streptomyces murinus (Novo } \\
\text { Nordisk, Denmark) }\end{array}$ & $\begin{array}{l}\text { Temperature } 60^{\circ} \mathrm{C}, \mathrm{pH} 7.5 \text {, Flow } \\
\text { rate } 7 \mathrm{~mL} / \mathrm{min} \text {, }\end{array}$ & 46 & $\begin{array}{l}\text { (Khalilpour \& } \\
\text { Roostaazad, } \\
2008 \text { ) }\end{array}$ \\
\hline Arthrobacter nicotianae & Temperature $70^{\circ} \mathrm{C}, \mathrm{pH} 7$ & 40 & $\begin{array}{l}\text { (Kovalenko, } \\
\text { Perminova, } \\
\text { Chuenko, } \\
\text { Sapunova, } \\
\text { Shlyakhotko, } \\
\text { \& Lobanok, } \\
\text { 2011) }\end{array}$ \\
\hline $\begin{array}{l}\text { Streptomyces murinus (Sweetzyme, } \\
\text { Novozymes) }\end{array}$ & $\begin{array}{l}\text { Temperature } 70^{\circ} \mathrm{C}, \mathrm{pH} 8 \text {, Flow rate } \\
\text { of } 8 \mathrm{~mL} \mathrm{~min}^{-1}\end{array}$ & 20.2 & $\begin{array}{l}\text { (Rahman, } \\
\text { Hussain, \& } \\
\text { Jahim, 2012). }\end{array}$ \\
\hline $\begin{array}{l}\text { Streptomyces (Genencor } \\
\text { International (Rochester, NY)). }\end{array}$ & $\begin{array}{l}\text { Temperature } 60^{\circ} \mathrm{C}, \mathrm{pH} 8.5, \text { Flow } \\
\text { rate of } 22.8 \mathrm{~mL} \mathrm{~h}^{-1}\end{array}$ & 44 & $\begin{array}{ll}\text { (Ge, } & \text { Zhou, } \\
\text { Kong, } & \text { Tong, } \\
\text { Wang, \& Li, } \\
\text { 1998). }\end{array}$ \\
\hline
\end{tabular}

Go back to Table S2 